IZA DP No. 6561

Do Significant Immigrant Inflows Create Negative Education Impacts? Lessons from the North Carolina Public School System

Timothy M. Diette

Ruth Uwaifo Oyelere

May 2012 


\title{
Do Significant Immigrant Inflows Create Negative Education Impacts? Lessons from the North Carolina Public School System
}

\author{
Timothy M. Diette \\ Washington and Lee University \\ Ruth Uwaifo Oyelere \\ Georgia Institute of Technology \\ and IZA
}

Discussion Paper No. 6561

May 2012

IZA

P.O. Box 7240

53072 Bonn

Germany

Phone: +49-228-3894-0

Fax: +49-228-3894-180

E-mail: iza@iza.org

Any opinions expressed here are those of the author(s) and not those of IZA. Research published in this series may include views on policy, but the institute itself takes no institutional policy positions.

The Institute for the Study of Labor (IZA) in Bonn is a local and virtual international research center and a place of communication between science, politics and business. IZA is an independent nonprofit organization supported by Deutsche Post Foundation. The center is associated with the University of Bonn and offers a stimulating research environment through its international network, workshops and conferences, data service, project support, research visits and doctoral program. IZA engages in (i) original and internationally competitive research in all fields of labor economics, (ii) development of policy concepts, and (iii) dissemination of research results and concepts to the interested public.

IZA Discussion Papers often represent preliminary work and are circulated to encourage discussion. Citation of such a paper should account for its provisional character. A revised version may be available directly from the author. 


\section{ABSTRACT \\ Do Significant Immigrant Inflows Create Negative Education Impacts? Lessons from the North Carolina Public School System}

The influx of immigrants has shifted the ethnic composition of public schools in many states. Given the perceived negative impact of significant immigrant inflows, we are interested in investigating if these inflows into a school affect the academic performance of native students who remain. To address this question, we analyze education data from North Carolina, a state that has experienced a significant immigrant influx in the last two decades. We focus on the share of the English Language Learners in the student population for students between fourth and eighth grade over the period from 1999 to 2006 and the potential effects of the presence of these students on the level of achievement in math and reading for native students. Our analysis suggests some evidence of immigrant peer effects though the effects are heterogeneous. Specifically, we find some evidence of positive effects among those in the middle and bottom portions of the achievement distribution while we find small negative effects at the top of the distribution.

JEL Classification: $\quad$ I20, I21, J15, J24

Keywords: immigrants, student achievement, peer effects, education

Corresponding author:

Ruth Uwaifo Oyelere

School of Economics

Georgia Institute of Technology

221 Bobby Dodd Way

Atlanta, GA 30332

USA

E-mail: ruth.uwaifo@econ.gatech.edu

\footnotetext{
* This research has been supported by the Mednick Memorial Fellowship Grant, the Ivan Allen College Special Research Award, and Summer Lenfest Grants. We want to thank seminar participants at the University of Texas at Dallas and conference participants at APPAM. All remaining errors are ours.
} 


\section{Introduction}

Over the last two decades, immigrant inflow into the U.S. (both legal and illegal) increased dramatically. The diversity lottery provided one source of this increase while political instability in many parts of the world led to an increase in immigrant influx on refugee status. In addition to this legal source of increased immigration was the increase in illegal immigrants from Mexico, Central America, and South America fostered by the temporary agricultural worker program and the housing boom in the mid 90s.

The rise in immigrants, particularly from Latin America, has sparked debates on immigration and created a backlash against immigrants among certain groups. The influx of immigrants has shifted the ethnic composition of public schools in many states and anecdotes claim that the influx of immigrants has negatively affected those who live in the communities where they settle. Given the perceived negative impact of significant immigrant inflows, this study will investigate the validity of some of these claims as it relates to academic performance.

Specifically we investigate two important questions that allow us to capture potential immigrant peer effects. First, do significant immigrant inflows into a school affect the academic performance of native students who remain? Second, are these immigrant peer effects distributed evenly or do they differ by academic achievement level? ${ }^{1}$

\footnotetext{
${ }^{1}$ We separate students by test performance quartile within their grade in the state in a given year for math and English. We then examine the top 25 percent, middle 50percent, and bottom 25 percent.
} 
We are not the first to consider the impact of immigrant peers on the educational outcomes of native students. Gould, Lavy and Paserman (2009) address a similar question exploiting the mass migration wave to Israel in the 1990. One major difference between their paper and ours, apart from the different country context, is that they concentrate on long-term effects on education outcomes while we focus on short-term effects. Specifically we focus on the effect of immigrant shares on achievement from one grade to another while they focus on the impact of the share of immigrant exposure in 5th grade on the probability of passing a high school matriculation exam. Another paper related to ours but not focused on immigrant peer effects is Haushek, Kain and Rivkin (2009). Their paper looks at the effect of having a higher concentration of Black schoolmates on the outcomes of Black and White students. Though their paper is focused on having Black schoolmates and ours is focused on having immigrant school mates, the mechanism of impact and potential premise of impact are similar. Both the immigrants who are the focus of the debate and Blacks are on average economically disadvantaged and are presumed to create negative externalities or peer effects on the reference group (in our case natives).

To address these questions, we analyze education data from a state that has experienced a significant immigrant influx. Between 1990 and 2000, North Carolina ranked highest among all states in the change in its immigrant population North Carolina had a foreign born population of just 1 percent in 1990 which rose to 7 percent by 2008. This upward trend in the immigrant population is reflected in our data in which we track students who are classified as English Language Learners, a proxy for immigrants, over time (see Figure 1). We make use of detailed restricted individual level data on students and their schools over time. This data is made available through the North Carolina Education Research Data Center (NCERDC). 


\section{$<$ Insert Figure 1 Here $>$ \\ $<$ Percent Limited English across Time $>$}

We approach answering our questions using the value-added approach common in the literature. Specifically, we estimate the impact of the level of limited English shares within a grade in a school on native student performance in time t controlling for performance in previous period. However, given the limitation of this approach we conduct further empirical analysis controlling for potential selectivity issues using multiple fixed effects specifications.

We initially address these potential selectivity issues by re-estimating our empirical models using school level fixed effects. Given the potential of further selectivity issues within a school, we conduct further analyses including either school-grade or school-year fixed effects. The school-year fixed effects allow us to identify the effect of the share of immigrants across grades within schools in the same year. This addresses the potential concern that schools may become more or less attractive over time and could bias our estimates. The school-grade fixed effect in contrast allows us to deal with any potential across grades differences. We also estimate a model with individual fixed effects. We make use of the same methodology in addressing our second question, the only difference is that we stratify the sample into different groups. First, we look at those at the top of the achievement distribution (top quartile), subsequently we analyze those at the bottom and last we consider the middle 50 percent. As a robustness check, we analyze all our specifications using different thresholds of immigrant shares within a school. Specifically we look at all schools, then we restrict our analyses to schools that experience a 
positive number of immigrant students, then schools with more than $1 \%, 4 \%, 10 \%$ and $20 \%$ within at least one grade in one year in the sample respectively.

It is important to note that there is no question in the NCERDC survey that indicates an individual's citizenship status. Therefore to identify potential immigrants we use a proxy variable, students with limited English. The North Carolina data identifies students with limited English which by default are expected to be immigrants. However, we acknowledge that this proxy likely does not capture all immigrant students especially those from countries where English is the native or commonly spoken language such as in England, Ireland Australia, and New Zealand. We are not worried about this limitation for two reasons. First, the demographics of North Carolina suggest that this would only represent a small share of immigrants. Moreover, non-English speaking immigrants, particularly those from Latin American, have been the focus of recent debates on immigration. Hence our proxy variable focuses on those whose potential peer effects are being questioned.

Our results suggest that including teacher and school level characteristics are useful. More importantly, we provide evidence of peer effects. We show that an increase in immigrant students on average creates a slight negative externality on native students' performance in reading and math. However, this effect is restricted to those at the top of the achievement distributions. In contrast we find no negative immigrant peer effects at the middle and bottom of the achievement distribution. Although our individual level fixed effects suggest positive effects, we are worried that these estimates could be biased given our inability to control for 
potential time varying parental inputs which could be linked with parents' perception of the changing conditions in the school and classroom.

The remainder of this paper is organized as follows. Section 2 presents the literature review. Section 3 details the data we will be using. Section 4 provides some summary statistics. Our methodological approach for answering the research questions is in section 5 . Section 6 highlights our preliminary and primary results. Our robustness checks on the sensitivity of our results are in section 7 . We conclude in section 8.

\section{Literature Review}

There is a large literature on student academic performance and how it is influenced by innate ability, family, peers, neighborhoods, teachers and schools.

Parental influence or human capital is one factor that can play a role in student performance (see for example Painter and Levine 2000). Teachers also play an important role in student achievement. Clotfelter, Ladd, \& Vigdor (2007), using data for North Carolina public schools, show that teacher's experience, test scores and regular licensure all have positive effects on student achievement. Similarly, Rockoff (2004) find that teacher quality raises test scores. Specifically he finds that one standard deviation increase in teacher quality cause an approximately 0.1 standard-deviation increase in math and English achievement. Hanushek \& Rivkin (2009), using Texas administrative data, also find evidence of the impact of teacher specific characteristics in widening the achievement gap between Blacks and Whites. 
Quality of schooling is yet another factor that can affect students’ performance and several authors have provided evidence of the impact of this indicator (e.g. Hanushek, 1986, Ehrenberg and Brewer, 1994). Most of these papers show average school quality affects student performance. However, the impact of school performance or quality on student achievement can be multifaceted. Eide and Showalter (1998) provide evidence of this. Their analysis suggests that some measures of school performance may have positive effects at points in the conditional distribution of test score gains other than the mean.

There are other factors that researchers have shown to affect achievement. The effect of self esteem was considered by Bankston III and Zhou (2002) while the impact of human, cultural and social capital was considered by Perreira, Harris and Less (2006). Race, immigration status, and ethnicity are also factors to consider in thinking about differences in achievement. Differences in achievement based on these factors have also been documented by several authors. ${ }^{2}$ Evidence of racial difference in academic performance is not restricted to the U.S. Similar trends have been noted in other developed countries such as the U.K (see Drew and Gray (1990) and Demie (2001)).

As with the research across race, there are few widely accepted explanations for the differences across immigrant groups/ethnicity. Gilick and White (2003) shed some light on what could explain a part of this difference across groups of immigrants. They show that the social environment experienced in the United States is a good predictor of the trajectory of achievement. Language is yet another factor that can explain differences in achievement for

\footnotetext{
${ }^{2}$ For example see Fryer and Levitt (2006), Fryer and Levitt (2004), Clotfelter, Ladd and Vigdor (2007), Fuligni ( 1997), and Rumbaut ( 1995)
} 
immigrants. White and Kauffman (1997) note that English language proficiency is a strong predictor of education outcomes. There is also research that shows bilingualism can enhance school performance. The overwhelming majority of studies have found strong positive relationships between English-language proficiency and education. Interestingly, there is also evidence that bilingualism enhances school performance more than English proficiency (Glick and White 2003).

Peers are another factor that has been documented to affect achievement. This literature is extensive and though many of these papers provide evidence of peer effect, many of these papers find effects that are small and heterogeneous across race and ethnicity ${ }^{3}$. Hanushek, Kain and Rivkin (2009) find that among Black students, having a higher percentage of Black schoolmates reduces achievement for Blacks but not for White classmates. Angrist and Lang (2004) also find heterogeneous effects. They look at the effect of Metco, a program that sends students from Boston schools to more upper class suburban schools, on non-Metco students. Their findings suggest no effect on White students but modest effects on minority female students. Similarly, the importance of student composition was highlighted in Rumberger and Palardy (2005). They look at the impact of student composition on academic achievement in high school and finds that the average socioeconomic level of a students' school has as much impact on their achievement growth as their own socioeconomic status, net of other background factors.

In our paper we are focused on the effect of a subgroup of peers, immigrants, on the academic achievement outcome of natives. We are not the first to think about possible effects of an

\footnotetext{
${ }^{3}$ Other papers documenting peer effects are Hoxby (2000), Evan et al (1992), Hanushek et al (2003) and Ammermueller and Pischke (2006).
} 
increase in immigrant on natives in the United States. Hoxby (1998) and Borjas (2007) both look at whether immigrants crowd-out natives from slots in college and graduate programs. At the pre-college level, Betts and Fairlie (2003) provide some evidence of immigrants crowding-out natives to private schools in California. Similarly Betts (1998) investigates whether immigration affects the probability of high school graduation of American born minorities. Her results suggest strong negative effects on African Americans and Hispanics, although the effects on Hispanics are not robust to the exclusion of California. Several of the papers that have investigated the impact of immigrants have looked at the effect on dropping-out of high school and student flight. We focus on possible effects on achievement (test scores). One paper that has also focused on student achievement is Gould et al (2009). They examine the long-term academic effect of immigrant concentration in elementary school in Israel on passing a high school matriculation exam. Their results suggest negative effects of higher immigrant concentration in elementary school. This paper looks at long term effects. In our paper we looking at short term exams and focus on changes in test scores versus passing or not passing an exam.

Past research similar to our paper is Santillano (2009). He uses the North Carolina data we use to test for peer effects of English learners on others in public elementary schools, controlling for potential adverse selection. He makes use of matching estimators and focus on 4th and 5th grade. He finds small effects, that are both positive and negative and although he notes statistically significant difference across demographic groups by type of effect, he finds that few individuals were influenced. Our paper differs from this paper in three ways. First, we focus on 4th to 8th grade outcomes which create the opportunity to do school-year fixed effects and also do school- 
grade fixed effects and individual level fixed effects as a robustness check. Second, we control for teacher characteristics which is not considered by Santillano (2009) in creating his matching estimator. The potential problem with not including teacher controls and matching across schools is that differences in performance linked with teacher differences or school quality could be attributed to immigrant peer effects. Third we make use of a different methodology to identify the impact of increased immigrants share on native student achievement. This methodology is more consistent with the aforementioned literature that looks at student performance and factors that affect this performance. Although the matching estimation process used by the other is unique, the methodology requires several restrictions that lead the author to drop a portion of the data and interpretation of the finding is less clear.

In this paper we explore this question of peer effects further. We include teacher and other school related controls, use more data years and explore restrictive fixed effect methods that can deal with multiple types of selection issues. To the best of our knowledge we are the first to consider possible peer effects of immigrants in this manner using North Carolina public school data.

\section{Data}

For this analysis we make use of administrative records created by the North Carolina Department of Public Instruction. This data is cleaned and maintained by the North Carolina Education Research Data Center (NCERDC) at Duke University. The datacenter contains the education data we need to investigate our questions of interest. This data record has detailed and reliable information on both students and teachers. Student performance can also be tracked in a 
consistent way across school years. Students are required to take tests in reading and math at the end of each grade from third to eighth grade. ${ }^{4}$ This yearly testing of students from third to eighth grade with tests designed by the state provides an opportunity to monitor the same students' academic performance and progress over a significant amount of time. For our analyses we use data from 1998 to 2006. We choose these years of data because they have information that could serve as controls in our analysis. In particular the free lunch variable is a good proxy for income level of a student's family and economic condition. This variable is not available in earlier years of data. Similarly the variable we use as a proxy for immigrants, limited English is redefined in 2007. This change makes it more difficult to identify potential immigrants post 2006.

\section{Descriptive Statistics}

In Table 1 we summarize the data according to race and English speaking ability. Notice that among the immigrant population, immigrants with Latin decent are the majority group representing over 75 percent of English Language Learners. The next largest group, individuals with identified as Asians, only account for less than 15 percent of the immigrant population. White and Black immigrants are only a small proportion of the limited English students. This break down is quite different for the English speaking or non-immigrant student where Whites represent over 62 percent of the fourth through eighth grade non-immigrant public school population in North Carolina during the sample period. Black persons account for 31 percent of this group and followed by Hispanics at only 2.1 percent. In fact, there are more Latino English Language Learners $(144,669)$ than those proficient in English $(83,863)$.

\footnotetext{
${ }^{4}$ For more on the administrative data we plan on using see Clotfelter, Ladd, Vigdor (2009).
} 
$<$ Insert Table 1 Here $>$

<Table 1: English versus Limited English speakers by race>

Students who are classified as Limited English at some point during their fourth through eighth grade come from families with a significantly lower level of parent education (see Figure 2). Over 43 percent of immigrants in the data have parents who did not graduate high school compared to just 8 percent of native students. When paired with the large literature on the role of family and peers this gives rise to some concern that the immigrants may have negative effects on native students.

\section{<INSERT FIGURE 2 HERE>}

<Figure 2: Trend in English vs Limited English Speakers>

As a result of the increase in the percent of immigrants in North Carolina in recent years, students are significantly more likely to have peers who are learning English. Native students from all backgrounds have seen similar increases in the share of peers with limited English skills (see Figure 3), although students in suburbs and particularly cities have seen larger increases in immigrant students that native students that live in town or rural areas.

$<$ INSERT FIGURE 3 HERE $>$

<Figure 3: Percent Current Limited English Exposure by Native Parent Education> $<$ INSERT FIGURE 4 HERE $>$ 
$<$ Figure 4: Percent Current Limited English Exposure by School Location and Year>

These trends in limited English speakers is a lower bound on the increase in immigrant population to the North Carolina public school system given that immigrants from English speaking countries are not captured. Figure 1 earlier showed that the absolute number of immigrant students has increased by almost than 300\% between 1999 and 2006 and Figures 3 and 4 highlight the changing composition of the peers within schools.

In our estimation of student performance characteristics other than peers likely play a role as well. Table 2 is a summary of mean z scores for math and reading for different groups in the population of native speakers, the focus of our investigation. Panel A shows that females students outperform males on average with a larger advantage in reading. Students from families who are not eligible for a free or reduced price lunch at any point during $4^{\text {th }}$ through $8^{\text {th }}$ grade have a roughly 0.8 standard deviation advantage in both math and reading (shown in Panel B).

In Panel C we separate the English speaking portion of the population into three groups by the share of immigrants in the grade. One group has no immigrant students in their grade, the medium has grades with typical percentage of students with limited English representing roughly the middle 50 percent of the distribution (greater than zero and up to 3.82 percent of the students in the grade) and the remaining students - those in the top quartile of share of limited English students in their grade_-are classed as high. Students in the middle group have the highest level of achievement although these differences in achievement are insignificant compared to differences from individual level characteristics. 
The large achievement gap by parent education is reported in Panel D with approximately 1.5 standard deviation gap in performance between the average child with parents who did not graduate high school and one with parents who have a graduate degree. Finally, Panel E shows the well-documented racial and ethnic achievement gap. Appendix 1 reports the mean values of the comprehensive list of control variables for the full sample, for the top quartile of math performers, the middle 50 percent, the bottom quartile of math performers, and the subsample of individuals who attended schools with at least 20 percent of students with limited English in one grade in one year in the sample.

\section{Methodology}

We have two questions of interest: Do significant immigrant inflows into a school affect the academic performance of native students who remain; and are these effects if any distributed evenly within the population or do they differ by student's ranking? We address these related questions first using ordinary least squares controlling for the share of limited English students in the grade, previous achievement of the student in the same subject, parent education, race/ethnicity, year fixed effects, grade fixed effects, and eligibility for free lunch and reduced price free lunch, which we believe could be used as a proxy for family's economic status. We then introduce controls for peers given the general literature on peer effects using racial composition of peers and share of students eligible for free lunch and reduced priced price. Subsequently, we further control for school related variables that could also potentially affect students’ performance and are correlated with immigrant exposure including pupil teacher ratio, 
status as a charter or magnet school, school level free and reduced price lunch eligibility, and urbanicity of the school. Next, we include teacher level controls which are typically not included in many analyses looking at achievement because of the difficult in acquiring this information. Despite these controls we are still worried about potential unobservable that could differ across school and could affect student achievement and possible biases associated with selection into schools.

Identification of the effect of immigrant inflow on academic performance can be difficult because immigrant inflow to a school or the allocation of immigrant students to a school is not exogenous or random but as a result of other choices of families or government. The potential endogenous nature of the immigrant inflow variable makes it hard to identify its causal impact on native student achievement outcomes. Even if we include a series of controls, there may be other family, teacher and school influences that foster achievement that we may be unable to control for. The presence of such confounding influences related to both achievement and immigrant inflow makes estimations using simple OLS models and controlling for observed factors that affect achievement, deficient. To avoid this potential problem in our analysis, we make use of two alternative approaches. In each of these approaches we make use of panel data from North Carolina public schools to estimate the impact of immigrant flows. Moreover, by using panel data, we can control the precision of our estimates by including fixed effects. Our fixed effects allow us to account for choices by schools, or parents that could be correlated with student achievement and threaten the identification of the effect of immigrant shares. 
Given the potential heterogeneity of effects by certain groups, we estimate separate regressions by level of achievement ${ }^{5}$. The importance of running different regression by level of achievement is especially useful because the quality of education may vary systematically by achievement level within school given the tracking system in many public schools in the U.S. Moreover by looking at these subgroups, we can avoid constraining the school, year and grade fixed effects for these various groups to be equal.

Our approach is to estimate equation 1 highlighted below using a value added approach and improving the precision of our estimates by including fixed effects. This value added approach is one used commonly in the literature.

$$
Z_{i g s t}=\beta_{0}+\gamma Z_{i s(t-1)}+\beta_{1} I_{i g s t}+\delta X_{i g s t}+\mu T_{i g s t}+\delta S_{i g s t}+\alpha_{i s}+\varepsilon_{i s t} \quad \text { equation } 1
$$

In equation $1 Z_{\text {ist }}$ is the $\mathrm{Z}$ score in math or English of student $\mathrm{i}$ in grade $\mathrm{g}$ and school $\mathrm{s}$ in time period t. $I_{g s t}$ is the immigrant share in student population in grade $\mathrm{g}$ in school s in time period t. $\alpha_{s}$ is a school fixed effect. $\mathrm{X}$ is a matrix of individual characteristics and $\mathrm{T}$ is the matrix of observable teacher variables that affect achievement. $\mathrm{S}$ is a vector of school related variables that could affect achievement. $Z_{i s(t-1)}$ captures an individual's achievement in period t-1. This variable characterizes the knowledge or skills students have at entry to a grade and are affected by prior family, neighborhood, or school experience and individual's ability.

\footnotetext{
${ }^{5}$ In a separate paper we address potential heterogeneity across race and gender.
} 
The value added approach with school-year fixed effect is our preferred model. However, we present other alternative specification with less restrictions given the potential loss of precision in our estimates with our school-year fixed effects specification .

The basic problem of the value added approach without fixed effects is that the estimate of the impact of the variable we are interested in could be biased for several reasons. First, the immigrant share in a grade in a school is correlated with the immigrant share in the school as a whole which is endogenous. The choice of schools by immigrants is nonrandom and to the extent that immigrants choose schools on some unobservables that might be correlated with achievement, we will be over estimating the impact of immigrant share. One way of dealing with this problem is to introduce school effects. However, there are other potential selectivity issues which school fixed effects cannot deal with. We introduce school by year fixed effects and school by grade fixed effects to deal with these problem. In each model we calculate robust standard errors given the presence of individual and school-level variables in the equation above using the Huber/White/Sandwich estimator of variance.

Our expectation is that if we include prior year score, parent education, teacher and school related characteristics and exploit fixed effect, then any variation in immigrant inflow left will be uncorrelated to the error term. If $\beta_{1}$ is negative and significant in equation 1 then share of immigrant in a student's grade is creating some negative externality and if $\beta_{1}$ is positive and significant then there is evidence of some positive externality. However if $\beta_{1}$ is not significant then share of immigrant students in a grade does not have an impact on students' performance in Math or English. 
In addressing our question using any of the estimation strategies, we restrict ourselves to students who do not change schools within the time periods we are examining. Second we focus our attention on the impact of immigration flow on nonimmigrant students. Our estimates do not tell us anything about the impact of immigrant flow on immigrant students or students in general.

\section{Results}

[insert Table 3: here]

Table 3 summarizes the results for our base Math models and modifications to this model to deal with potential omitted variable bias and possible endogeneity of our dependent variable. Table 4 summarizes our results for English. Although in table 3 we display most coefficients for our math models, to highlight the variables we control for on our different specification, we only show a select number of variables in Table 4 which summarizes our results for reading. ${ }^{6}$ In each of the specifications in Table 3, a student's math $\mathrm{z}$ scores for the current year is our dependent variable and we control for prior year performance. The estimates summarized in columns (1)(4) of Table 3 are derived a using an OLS regression framework. For the results summarized in column (1) our reference model, we control for parent's education using parent education dummies. These variables capture if a student's parent has some college, a bachelor degree, advanced degree or is a high school dropout. The base group is parent has a high school degree. The signs are in the expected direction and suggest the importance of parents' education in children's performance over time in math. We also control for gender, if a child has ever been on the free lunch program and if a child has ever been on the reduced lunch program. We do not use

\footnotetext{
${ }^{6}$ We only show a select set of variables in Table 6 to reduce the length of the Table.
} 
the yearly response of students to the question of if they are using the free lunch or reduced lunch program given the noted trend that older kids may not want to reveal they are on this program because of the potential stigma. We use these variables to capture family income levels which are also potentially important variables that affect achievement. We also control for the year and grade an individual is in using year and grade fixed effects.

The result in column (1) suggests that an increase in exposure to immigrant inflows reduces a student's math Z scores. However this result could be biased given the use of a naive OLS regression without controls for peer effects, school and teacher characteristics. In column (2) we control for possible peer effects by including in each year, the share of students in each grade by ethnicity. We also include for each year, in each grade the share of students who participate in the free-lunch program and those who participate in the reduced lunch program. Our estimate of the impact of immigrant inflows reduces slightly but is still negative and significant. Again the estimated impact of being exposed to increased immigrant inflows in column 2 could be biased because of unobservable about the school which could be correlated with both immigrant inflow achievement. In column (3), we build on the model summarized in column (2) by including school level characteristics. We include dummies for if a school is a charter school or magnet school. We also control for the percent of the school that has reduced or free lunch in each given time period and the teacher pupil ratios which could proxy for school quality. Given the potential importance of school location for education outcomes, we include dummies for location (city, town, and rural with suburb as the reference group). The inclusion of these school related controls leads to a reduction in the estimated impact. However, our coefficient of interest is still negative and significant (-0.0155) suggesting an increase in immigrant shares leads to a decline 
in a student's z score in Math. Even with the inclusion of school level characteristics, the estimated impact of immigrant inflows could still be upward biased because we do not include information about teachers. There is a wide literature documenting the importance of teacher characteristics on students learning outcomes (Rockoff 2004 and Hanushek and Rivkin (2009). Hence, controlling for teacher characteristics in our analysis could be useful in reducing possible bias in the estimate in column (3). Teacher characteristics are hard to control for generally especially when students begin to have teachers for specific classes in middle school. Even in some elementary school, students leave their homeroom to take classes in math making it harder to keep track on which teacher matters more in influencing students outcomes. The teacher information can also be challenging to work with for several reasons. For example, we include a measure of the average teacher test score as a measure of teacher ability. However, teachers take different exams in different years and the tests are not necessarily written to be comparable across years. Therefore, a z-score has to be calculated for each test-year combination. In addition, teachers can take multiple tests and decisions must be made on how to weight the multiple scores. Teachers frequently teach across grades and therefore it is challenging to match teachers to a specific grade. Finally, some data files may match the teacher to the student, but the teacher ID may be the teacher who administered the exam and this may or may not be the person who taught the class.

Given the aforementioned limitation to controlling for teacher characteristics at the grade level, we are only able to control for teacher characteristics at the school level for each time period versus the grade level which would have provided more information. However, due to the potential that assignment to teachers is nonrandom, even if teacher-student information is 
available, including this can cause other potential bias. The results in Table 3, column (4) suggests that including teacher variables even at an aggregated level is still very useful. Specifically we include the average number of teachers in a school that are female each year, the average number of teachers in a school in their first year of teaching. These variables are significant and take on the expected sign. Female teachers seem to be positively associated with better performance and experience of a teacher is associated with student performance. A school that has a higher percent of inexperienced teachers also has students with lower z-scores. We also control for the ethnicity of teachers using dummies that capture the average number of teachers by ethnicity. To control for teacher quality, we include the number of teachers with a masters degree in a school at a given time period and also includes a control for the average test scores of teachers in a school at a given point in time. Estimates of these variables have the expected sign although not always significant which is not unexpected given we are only including the means of these variables across schools.

The results in column (4) provide evidence supporting the need to control for teacher related variables. The coefficient of interest is still negative and significant, and the magnitude of the effect has increased from the estimated impact in column(3). The results for reading summarized in Table 4 follow similar patterns as Math. However, the magnitude of the estimate is slightly larger in 4 out of the five models. We find a small negative correlation between increase in the share of immigrant inflow and performance in reading.

Is the inclusion of our teacher, school and peer control variables sufficient to allow us say something about the causal effect of increased immigrant inflows on performance in math and 
reading? No, the inclusion of these variables is not sufficient. This is because of possible unobservables about schools that we still have not controlled for and could be correlated with performance on math and reading. One potential example is the overall quality of administration of a school. Assuming administration matters for school quality and school quality affects student achievement and performance, as long as immigrant inflows are not distributed randomly across schools, the estimated impact could be biased by the correlation between increases in immigrant inflow into a school and school administration. To address this potential source of selection we make use of school level fixed effects. The advantage of using school level fixed effects is that it allows us to estimate impacts based on within school differences versus differences across schools. Hence our within school variation comes from variation in exposure across grade and across time. ${ }^{7}$ The results in Table 3 and Table 4 column (5) are derived using a specification that includes school level fixed effects. For both math and reading, our results suggest a negative relationship between increase in the share of immigrants in a school and native students' achievement. However, the magnitude of the coefficients are small. In the next section of the paper we explore issues of heterogeneity in the immigrant share effect and also consider potential within school selection over time.

[Table 4: Preliminary Regressions for Reading here]

\footnotetext{
${ }^{7}$ We also control for variation across grade and time across schools'
} 


\subsection{Checking for heterogeneous effects and controlling for within school selectivity}

As mentioned above, though school level fixed effect can deal with a substantial part of the possible bias in our coefficient of interest, $\beta_{1}$, it is still possible that if we look within schools over time, there may be time-varying or non-varying unobservables that are correlated with immigrant share and also affect attainment. In Table 5 we summarize the estimates of $\beta_{1}$ using three possible ways of further controlling for selection. In column (1), in addition to our previous controls including school and teacher characteristics, we include a school by year fixed effect and in column (2) we include a school by grade fixed effect. In column (3), we estimate the model including individual level fixed effects.

\section{[Table 5: Effect of Increases in Immigrant shares on achievement ]}

The results for math are summarized in panel A of Table 5 while the results for reading are summarized in panel B. Each of these methods of addressing selection have strengths and weaknesses. One weakness common to each method is the loss of variation given the inclusion of these fixed effects. This could lead to large standard errors and loss of significance. When school by year fixed effects are introduced, we are identify effects within a school across grades at a specific period of time. The advantage with this specification is that it eliminates most plausible kinds of selection and casual impacts can be inferred. The only possible type of selection that it cannot deal with is if there is selection across grades within a school. It is hard to tell a story of selection across grades at a given period in time. To tell such a story, one would have to assume that parents or decision makers have information on the share of immigrants in each grade and take action whether or not to enroll their children in a school based on this 
information. Our research on North Carolina school districts does not provide any information to indicate such selection by parents is plausible or taking place. Moreover, knowledge on the share of immigrant student in a student's grade for the year would be available post the period when decision on enrollment is likely to take place which makes potential gaming of the system not very plausible. The main limitation of this specification is the reduced variation upon which we are identifying effects. We are identifying our impacts over differences across grades within schools and sometimes these differences across grades could be minimal.

The school by grade fixed effect addresses the improbable selection on grades by looking within a school and within a grade over time. The advantage of this setup is that we have more variation to identify our effects over. The disadvantage is that once effects over time are being considered, it is possible to tell a story that there could be unobservables correlated with students performance that are also correlated with increase in immigrants in a grade in a school over time. For example, as immigrants move into a neighborhood, good teachers and administration may also change schools if they believe an increase in immigrant families signals a decrease in the quality of school. In this scenario, as long as we do not control for school administration quality our estimate of the impact of the immigrant shares could be upward biased.

Including individual fixed effects is our third alternative specification. The advantage here is in estimating impacts based on variation in an individual's exposure to immigrant populations over time. This eliminates most of the selectivity that arises when we are comparing different individuals over time or at a given period in time. The disadvantage of this method is that it does not eliminate time varying unobservables that could be correlated with increased exposure to 
immigrants and affect performance. For example assume parents of natives exert effort in an attempt to aid their child's academic performance. If effort exerted varies over time and is negatively correlated with a parent's perceived impression on school quality or satisfaction, our estimated impact could be biased. This would occur specifically when such perception or satisfaction are also correlated with the share of immigrant students in a school.

Moreover, the student fixed effect specification also fails to capture unobservable about the schools that individuals attend that change over time and could be associated with increased immigrant inflows. Although we have controlled for school or teacher characteristics that could matter and are time-varying, we cannot rule out this possibility given we do not control for other measures of quality including management or administration.

The results using the three alternative specifications highlighted above are summarized in Table 5. However given the limitation with both the individual fixed effect and the school by grade fixed effect, our preferred specification is the school by year fixed effect with estimates summarized in column (1).

The results based on the inclusion of a school by year fixed effect suggests a negative significant impact of increased immigrant shares for both math and reading of about 0.0516 and 0.0579 respectively. Notice that the magnitudes of these estimates are slightly larger than the estimates in the prior tables without controlling for potential within school selection. 
The results using the school-by-grade fixed effect yield somewhat contrasting results. It suggests no statistically significant effects on reading scores but significant positive effects on math scores similar in magnitude as the negative effect noted using the school by year selection. Finding positive externalities from immigrant inflow is surprising giving the recent debates and claims of negative impact of recent immigrant inflow. The positive externality is not large but finding any positive externality is welcomed by those hoping to reduce negative view of immigrants. Off course this estimate could suffer from omitted variable bias as we mentioned earlier. In this analysis, we are identifying effects based on variation in limited English within a grade in a school across time. Meaning that it is possible that within a school and grade there are still unobservable characteristics that are time-varying and possibly correlated with the share of immigrants in a grade and also correlated with achievement.

The results using the individual fixed effect model suggests small significant positive effects for reading and small negative effects for math. The estimates are higher for math (-0.034) than reading (0.0244). These results for reading are compatible with the parent effort story we highlighted above. Specifically, more exposure to increased immigrant inflows could make parents less satisfied and more worried about the quality of education their children are getting. This could elicit more effort and involvement of parents which then leads to improved performance of children. This story is also a plausible explanation for finding positive effects in our school by grade specification. We acknowledge that these positive effects could be explained in alternative ways but the parent effort story is one possible explanation. Another possible explanation is that native parents whose kids are in schools experiencing a rapid growth in immigrants could push for an honors program or some form of a tracking system which will 
allow separate classes from most immigrant or low performing students which would boost their performance.

\section{[Insert Here Table 6]}

\section{Are these effects heterogynous?}

To test for the possible heterogeneity in impact of exposure to increased immigrant inflows, we divide the population by performance quartiles for math and reading. Specifically we analyze our two main specifications: school by year fixed effects and school by grade fixed effect separately for the top 25 percent, the bottom 25 percent and the middle 50 percent. Our results are summarized in Table 6. Panel A captures the estimated impacts for math and the results for reading are in Panel B. The results in this table provide evidence of heterogeneous impacts of being exposed to immigrant peers, within the population. We focus more on the results using the school by year fixed effect given the limitations of the school by grade fixed effect. Using this specification, we find evidence of significant negative immigrant peer effects for the highest performing students (top 25 percent) in both math and reading but no effect in both reading and math on the bottom 25 percent and the middle 50 percent. The estimated negative effect on the top $25 \%$ is larger than the average effects summarized in the earlier tables. Column (2) of Table 6 capture the estimated impacts when school by grade fixed effect are included. For math in panel A, these results suggest positive immigrant peer effects at the bottom and middle of the distribution but not at the top. In contrast, no effects for reading are noted using the school-bygrade effect specification. 
Overall, these results suggest that negative immigrant peer effects exist but the effect is heterogeneous within the population with no discernible negative effect on the bottom of the distribution which most policymakers would be most worried about and small negative effects at the top. These results also suggest that the noted negative effect highlighted in Table 3-5 are driven by the negative effect of increased immigrant shares on the top $25 \%$ of students. The results including school by grade fixed effects also has a plausible explanation. The lack of a positive effect in math for the top $25 \%$ in contrast to a significant positive effect for everyone else could be explained by teacher response. When the share of immigrant students increases in class, a teacher may feel more pressure to slow down the pace of the class to make it easier for these students to follow. They may also spend more time explaining concepts which then improves the performance of average or bottom performing native children but such effort do not benefit high performing students who may prefer a more challenging environment. . Another compatible story is one when parents who are worried about their children who are average achievers may put in more effort with respect to their child's learning including getting tutors when immigrant children increase in school, which may actually boost performance. Tutors are typically for Math and this might explain the lack of effect for reading for the bottom 25 percent and middle 50 percent of the distribution. Also the lack of positive effect on the top 25 percent also does not support the honor's program story mentioned earlier on in the paper.

The negative effect for English on the top 25 percent using the school-by-grade fixed effect is also compatible with our story. If teachers have to slow down the pace of the class or assigned readings because of the presence of immigrant students then students at the bottom and middle may benefit from the slower paced class. In contrast a slower paced class may be detrimental to 
higher achieving students who may get less challenging reading and be exposed to fewer opportunities to read more complex material or be challenged compared to other higher achieving students in schools with fewer immigrants. In the last section of the paper we conduct robustness checks to see if our results are sensitive to the share of immigrant students in a school.

\section{Robustness Checks}

Our results thus far suggest negative peer effects on high performing native students. We conduct robustness checks to test the sensitivity of our estimates to variation in the sample based on the magnitude of exposure to the immigrant peer effects native students face. In all our previous analysis we have included the sample of all schools whether or not they had immigrant students or an insignificant number of immigrant students. However, it is possible that a certain threshold in the size of immigrant students is necessary before any tangible impacts can be identified.

Given this possibility, we first restrict our sample to schools that have a positive share of students with limited English. Next we restrict our sample to schools with more than 1\% share, then schools with $4 \%$ share, $5 \%$ share, $10 \%$ share and finally $20 \%$ share. The results for this analysis using our alternative specifications are summarized in Table 7.

\section{[Insert here Table 7: Immigrant Peer Effects by Immigrant Thresholds]}

In panel A the results for math are summarized and in panel B the results for reading are summarized. The results in column (1) and (4) highlight estimates using the school by year fixed effect specification and in column (2) and (5) estimates using the school by grade fixed effect 
specification are reported. Columns (3) and (6) report the estimated impact using the individual effects alternative.

The results are generally similar to those found in Table 5. We find positive significant effects using the school by grade fixed effect and individual fixed effect for math at all thresholds. For reading we find no effects using the school by grade specification (column (5)) but we find positive effects using the individual fixed effects specification column (6) for thresholds of immigrants up to $4 \%$ and negative impacts at threshold's above $20 \%$. For our preferred specification (the school by year) column (1) and (4), we find negative and significant effects for both math and reading at all thresholds we examine. It is worth mentioning that the magnitude of the impact for immigrant threshold levels between 0 and $10 \%$ are small and similar to our previous estimates. $^{8}$

In contrast for schools with immigrant shares above the $20 \%$ threshold, the magnitude of the immigrant peer effect is relatively large and similar for both math and reading, ---0.083 and 0.086 respectively.

We test for the sensitivity of our results examining heterogeneous impacts across the achievement distribution using similar thresholds as above. These results are summarized in Table 8.

[Insert Table 8 Panel A and B: Robustness Checks on Heterogeneous Impacts here]

\footnotetext{
${ }^{8}$ We do not examine thresholds greater than $20 \%$ given the increased selection issues with schools that have such a high percentage of students who are immigrants.
} 
In panel A of Table 8 we summarize the results for the top $25 \%$ of students and in panel B we focus on the bottom 25\%. In Table 8 the results for the middle 50\% are summarized. These results suggest that our earlier inference of heterogeneous impacts is robust. Notice the negative peer effects for students in the top $25 \%$ of the achievement distribution for both math and reading. This negative estimated peer effect seems not to change significantly regardless of the immigrant exposure thresholds for math. In contrast for reading, the negative estimated peer effect seems to increase at above the $10 \%$ and $20 \%$ levels. However, the magnitude of the effect is still relatively small (less than 0.1 ). Just as in Table 6, we find a negative effect using the school-by-grade specification for the top $25 \%$ in reading. For math, just as in Table 6 , we find no effect regardless of the threshold of immigrant exposure. This implies our results are not sensitive to the restriction of the sample estimate based on different thresholds of immigrant share. For the bottom 25\% no negative effect was found regardless of the chosen threshold using the school-by-year specification for math but for reading we find a negative effect for schools with a share greater than $20 \%$. As in Table 6 , we find positive effects for math for the bottom 25\% using the school-by-grade specification and no effects for reading. These finding for the bottom $25 \%$ as most others we have mentioned above are not sensitive to different threshold of immigrant share exposure.

The sensitivity results for the middle 50\% are summarized in Table 8 . As in Table 6, we find positive effects with our school-grade specification in math and no effects in reading across thresholds. For our preferred specifications no matter our chosen threshold, we do not find any immigrant peer effects for this group in math. For reading we find no immigrant peer effects for 
thresholds up to $10 \%$. Beyond $20 \%$, we find negative peer effects but smaller than the estimated effect for reading at the same threshold for those in the top $25 \%$.

[Insert Table 8 Panel C: Robustness Checks on Heterogeneous Impacts [Middle 50\%] ]

\section{Inferences, Summary and Conclusions}

In this paper we focus on two basic questions: does exposure to increased immigrant shares create negative peer effects, and are these effects if any heterogeneous within the population? First, we make use of a simple somewhat naive linear regressions based on the value added approach to estimate such effects. However, given the potential selection and omitted variable bias in the estimated effects using this method, we explore alternative specifications that deal with these issues. First, we include school level fixed effects and given potential limitations even with school fixed effects, we explore school-by-grade, individual fixed effects and our preferred specification school-by-year.

Using our preferred specification, our results suggest negative immigrant peer effects in both math and reading but the magnitude is small. Second this negative peer effect is restricted to those in the top $25 \%$ of the performance distribution. For the bottom and middle quartiles, there are no effects as long as the immigrant threshold is up to $10 \%$. For schools with immigrant more than $20 \%$ we also find negative peer effects in reading for the bottom $25 \%$ and middle $50 \%$. .

It is important to mention that we note positive results when we use our individual level fixed effect and school-by-grade specifications. However given the potential of time varying 
unobservables, we are careful not to interpret these effects causally as being due to immigrant peer effects. We suggest one possible story for these positive effects based on the time varying effort of parents with respect to coaching and teaching their children to aid academic performance. If effort is negatively linked with parent satisfaction about their child's school or its quality, then performance could improve when parents feel quality has dropped but this is due to parents exerting more effort. The omitted variable bias arises with this estimation if a parent's perception of quality or satisfaction with a school is correlated with our variable of interest, share of immigrants in school. The fact that we do not see any positive effects at the top of the distribution which captures students who typically are highly motivated and may not need parental extra push supports this story. Similarly, finding positive effects of greater magnitude in math at the bottom in comparison to the middle quartiles is also compatible with our story given parents are more likely to be more concerned about their child if they are not performing well at school or performing at below an average level and accordingly exert more effort if they perceive the quality of the school may have something to with this outcome or could potentially make the child more vulnerable. Again we emphasize that this is one possible channel that could create the noted effects. Of course, we do not rule out other possible explanations for the positive findings. It is also useful to note that the negative effects noted at the top of the distribution in reading are not consistent with the honor or tracking program explanation.

Why could negative results arise for those at the top of the distribution? Most immigrant students especially those who are from non-English speaking countries struggle academically for the first few years after immigration because of language barriers. Teachers who have classes with at least one or two of such students may spend more time with such students or teach more at the 
average level which could create slight negative externalities for students at the top. Such negative externalities could show up at slightly lower performance in comparison to their peers of similar ability without such exposure.

Why are these results important? First, these results provide some evidence that increased immigrant inflows do not create negative peer effects on most students. Despite the negative effects on students at the top of the achievement distribution, such effects are small and below levels that raise concern within policy circles. Specifically, for example, the results for the top $25 \%$ in Table 6 suggest that a one standard deviation increase in the share of immigrant students would lead to a 0.003 decline in math $\mathrm{Z}$ scores and a 0.002 decline in reading $\mathrm{Z}$ scores which is an extremely small effect size. Given the increased perception of the negative impacts of immigrants, finding no impact at most levels and minimal impact at the top of the distribution is welcomed. One possible question we have not explored in this paper is potential heterogeneity in impact across race and gender. We are currently exploring these questions in another complementary paper.

It is important to mention again that results based on our preferred specification could potentially have some limitations. As mentioned earlier, we are assuming that there is no selection across grades within a school at a given point in time. Such an assumption though consistent with what we know about North Carolina and the public school stem in the U.S in general, may not always be valid. Though we cannot imagine why there would be unobservables across grades within a school at a given period in time that are correlated with immigrant shares, we cannot completely rule it out. 


\section{References}

Ammermueller, A., and Pischke, J-S. (2006). Peer effects in European primary schools: evidence .from PIRLS, Centre for the Economics of Education, Discussion Paper No. 65 May.

Angrist, Joshua D \& Kevin Lang, (2004). "Does School Integration Generate Peer Effects? Evidence from Boston's Metco Program," American Economic Review, American Economic Association, vol. 94(5), pages 1613-1634, December.

Bankston Carl L. III and Min Zhou (2002) Being Well vs. Doing Well: Self-Esteem and School Performance among Immigrant and Nonimmigrant Racial and Ethnic Groups Author(s): Source: International Migration Review, Vol. 36, No. 2 (Summer, 2002), pp. 389-415 Published by: The Center for Migration Studies of New York, Inc.'

Betts, Julian R., (1998), "Educational Crowding Out: Do Immigrants Affect the Educational Attainment of American Minorities?", in Daniel S. Hamermesh and Frank D. Bean (Eds.), Help or Hindrance? The Economic Implications of Immigration for African-Americans, New York: Russell Sage Foundation.

Betts, J.R. and Fairlie, R.W. (2003). Does immigration induce native flight from public schools into private schools, Journal of Public Economics, vol. 87(5-6) (May), pp. 987-1012.

Borjas, G.J. (2007). Do foreign students crowd out native students from graduate programs?, in (P.E. Stephan and R.G. Ehrenberg, eds.), Science and the University, pp. 134-49, Madison, WI: University of Wisconsin Press.

Clotfelter, Charles T. \& Ladd, Helen F. \& Vigdor, Jacob L., (2007). "Teacher credentials and student achievement: Longitudinal analysis with student fixed effects," Economics of Education Review, Elsevier, vol. 26(6), pages 673-682, December .

Drew , D and Gray J. (1990). The fifth-year examination achievements of black young people in England and Wales, Educational Research, 32, 2, 107-17.

Demie, Feyisa (2001) Ethnic and gender differences in educational achievement and implications for school improvement strategies Educational Research Vol. 43 No. 1 Spring 2001 91-106 .

Ehrenberg, R.G., Brewer, D.J., 1994. Do school and teacher characteristics matter? Evidence from high school and beyond. Economics of Education Review 13, 1-17.

Eric Eide, Mark H. Showalter (1998) The effect of school quality on student performance: A quantile regression approach. Economics Letters 58 (1998) 345-350.

Evans, W.N., Oates, W.E. and Schwab, R.M. (1992). Measuring peer group effects: a study of teenage behavior, Journal of Political Economy, vol. 100(5), pp. 966-91. 
Fryer Roland G. \& Steven D. Levitt, 2006. The Black-White Test Score Gap Through Third Grade, American Law and Economics Review, Oxford University Press, vol. 8(2), pages 249281.

Fryer Roland G. \& Steven D. Levitt, (2004) Understanding the Black-White Test Score Gap in the First Two Years of School. Review of Economics and Statistics, 2004, 86(2), pp. 447-64.

Fuligni, A. J. (1997) The Academic Achievement of Adolescents from Immigrant Families: The Roles of Family Background, Attitudes, and Behavior, Child Development, 68:351-363.

Glick Jennifer E and White Michael J (2003) The academic Trajectories of immigrant youths: analysis within and across cohorts. Demography, Volume 40-Number 4, November 2003: 759783

Gould, Eric D. \& Victor Lavy \& M. Daniele Paserman, (2009). Does Immigration Affect the Long-Term Educational Outcomes of Natives? Quasi-Experimental Evidence," Economic Journal, Royal Economic Society, vol. 119(540), pages 1243-1269.

Hanushek, E., (1986). The economics of schooling: production and efficiency in public schools. Journal of Economic Literature 24, 1141-1177.

Hanushek, E.A Kain, J.F., Markman, J.M. and Rivkin, S.G. (2003). Does peer ability affect student achievement?, Journal of Applied Econometrics, vol. 18(5), (September/October), pp. 527-44.

Hanushek \& Rivkin (2009). Harming the Best: How Schools Affect the Black-White Achievement Gap," Journal of Policy Analysis and Management, Vol. 28, No. 3, 366-393

Hanushek, Eric A., John F. Kain and Steven G. Rivkin. ( 2009) New evidence about Brown v. Board of Education: The complex effects of school racial composition on achievement. Journal of Labor Economics 27, 3.

Hoxby, C.M. (1998). Do immigrants crowd disadvantaged American natives out of higher education?, in (D.S. Hamermesh and F.D. Bean, eds.), Help or Hindrance? The Economic Implications of Immigration for African Americans, New York: Russell Sage Foundation,.

Hoxby, C.M. (2000). Peer effects in the classroom: learning from gender and race variation, NBER Working Paper No. 7867, August.

Rockoff, Jonah E (2004). The Impact of Individual Teachers on Student Achievement: Evidence from Panel Data American Economic Review, Papers and Proceedings, May 2004.

Rumberger, R. W. \& Palardy, G. J. (2005). Does segregation still matter? The impact of social composition on academic achievement in high school. Teachers College Record, 107, 19992045. 
Rumbaut, R. G. (1998) The New Californians: Research Findings on the Educational Progress of Immigrant Children. In California's Immigrant Children: Theory, Research, and Implications for Educational Policy. Ed. R. G. Rumbaut and W A. Cornelius. San Diego: University of California, San Diego, Center for U.S.-Mexican Studies.

Santillano, Robert. (2009) Essays on Immigrant Students in Public Schools-Evidence from North Carolina. Ph.D., University of California, Berkeley, 146 pp.

Painter, G. and D. Levine. (2000). Family Structure and Youths' Outcomes: Which Correlations Are Causal? Journal of Human Resources 35:524-49.

Perreira, K., Harris, K.M., Lee, D.(2006) Making It in America: High School Completion among Immigrant Youth. Demography 43(3): 511-536. 2006.

White, M.J. and G. Kauffman. (1997). Language Usage, Social Capital, and School Completion Among Immigrants and Native-born Ethnic Groups. Social Science Quarterly 78:385-98. 


\section{FIGURES}

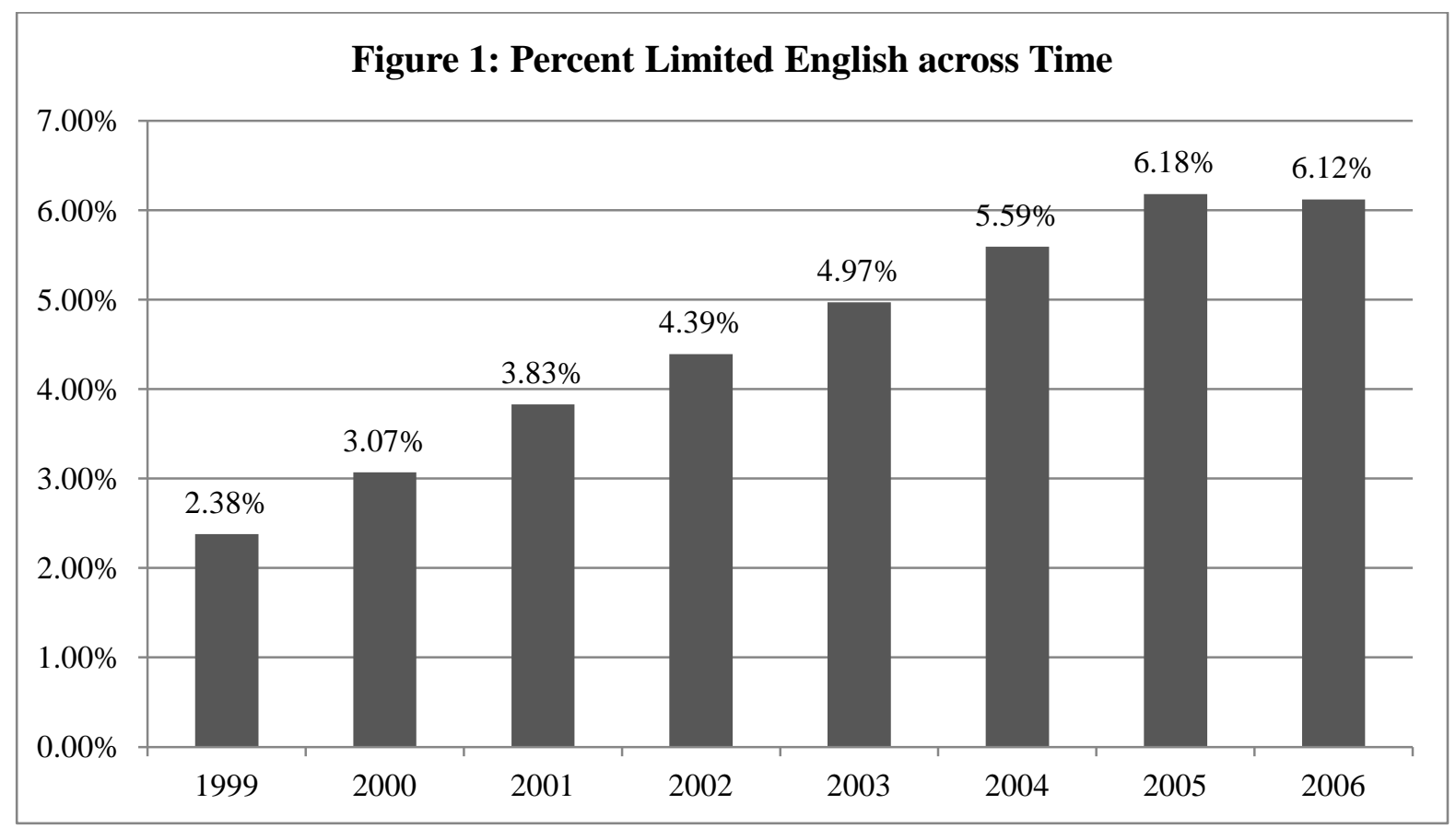

Figure 2: Parent Education Level

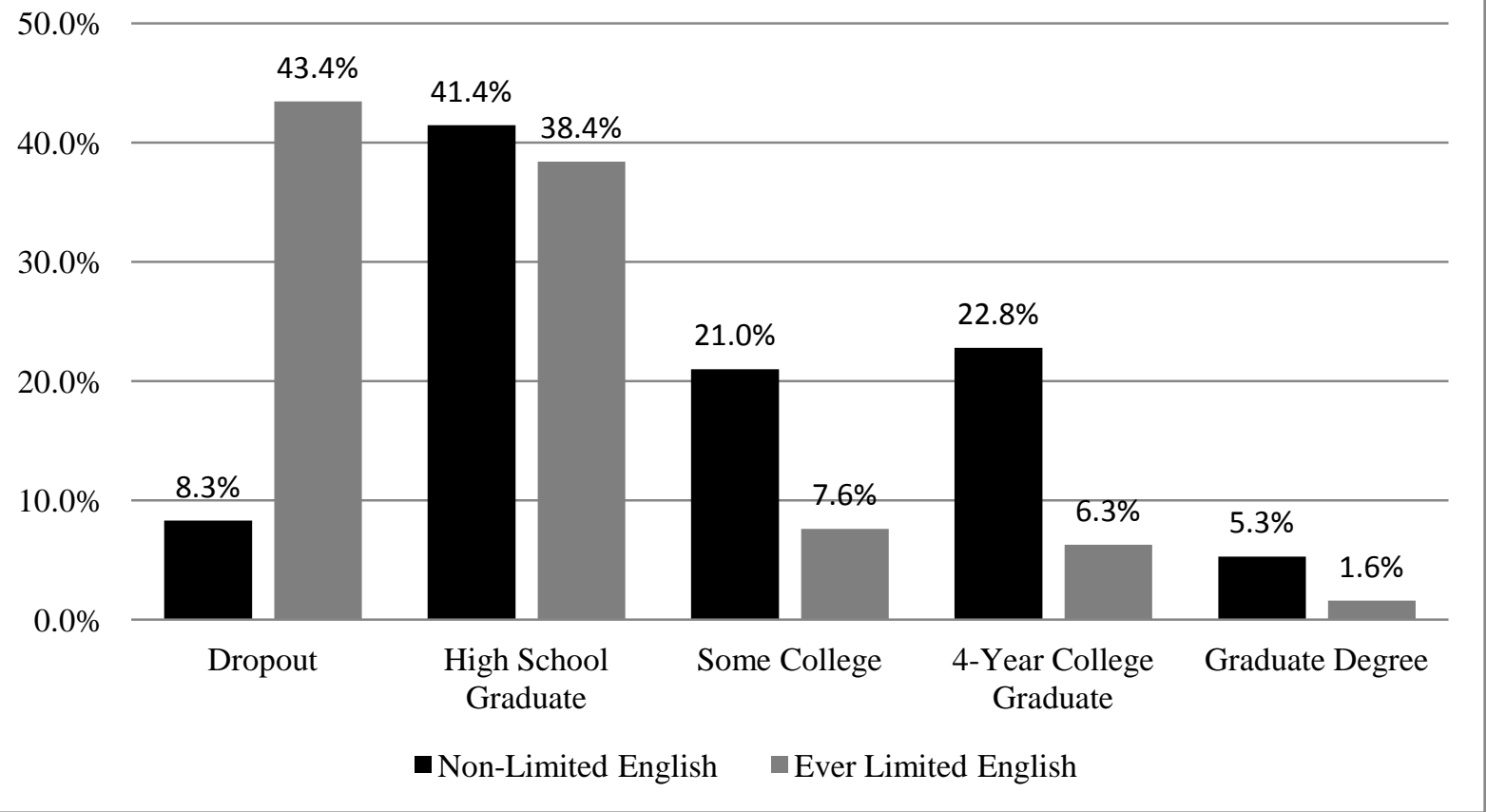



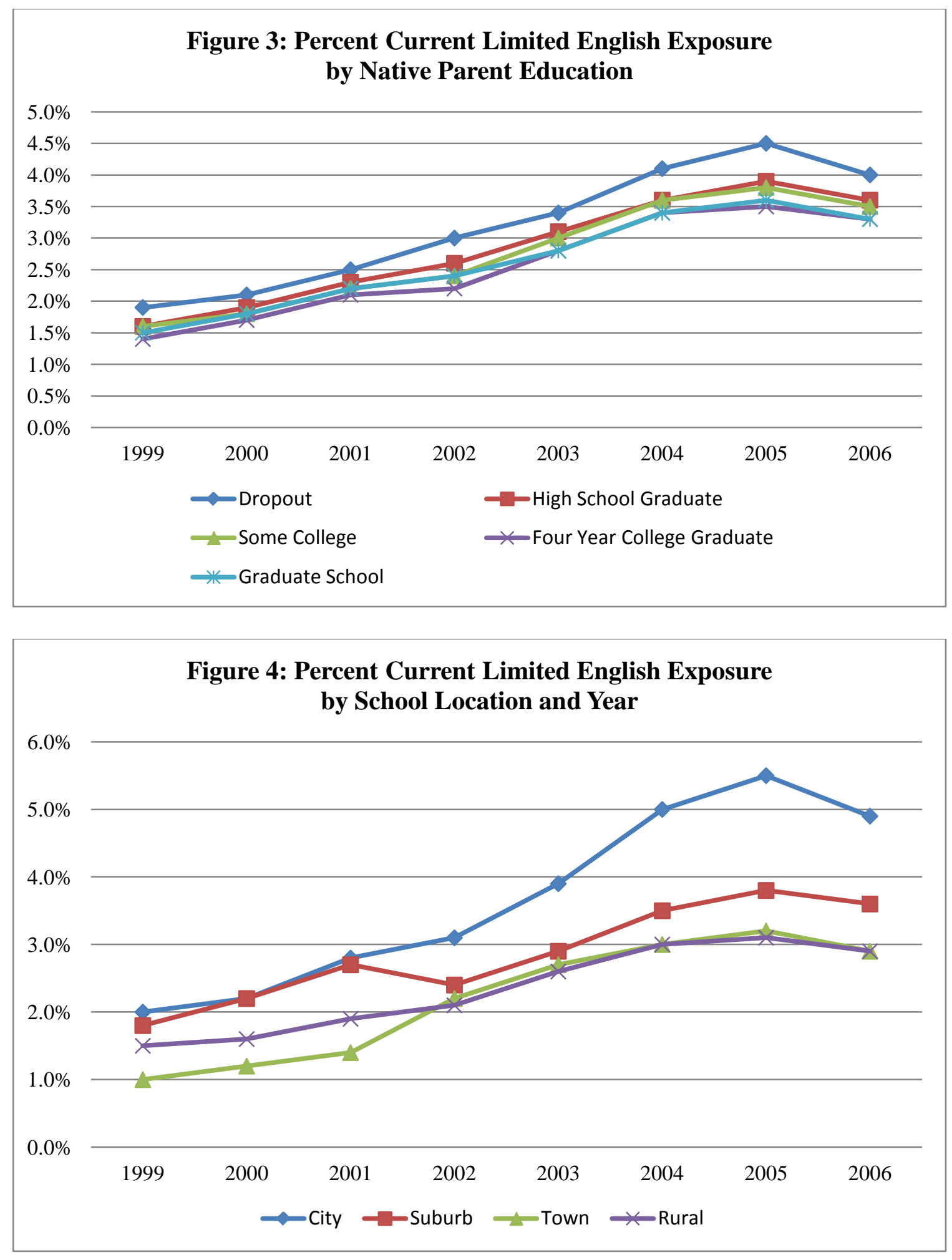


\section{Tables}

Table 1: English vs Limited English speakers by race

\begin{tabular}{l|rr|rr}
\hline & \multicolumn{2}{|c|}{ English Speakers } & \multicolumn{2}{c}{ Limited English Speakers } \\
Race/Ethnicity & Number & Percentage & Number & Percentage \\
\hline White & $2,471,488$ & 62.1 & 10,334 & 5.4 \\
Black & $1,245,698$ & 31.3 & 6,367 & 3.3 \\
Asian & 49,528 & 1.2 & 28,699 & 14.9 \\
Latino & 83,863 & 2.1 & 144,669 & 75.3 \\
American Indian & 60,345 & 1.5 & 304 & 0.2 \\
Multiracial & 70,424 & 1.8 & 1,761 & 0.9 \\
\hline \hline Total & & 100.0 & & 100.0 \\
\hline \hline Overall & $3,981,527$ & 95.4 & 192,142 & 4.6 \\
\hline
\end{tabular}

Table 2: Math and Reading Achievement

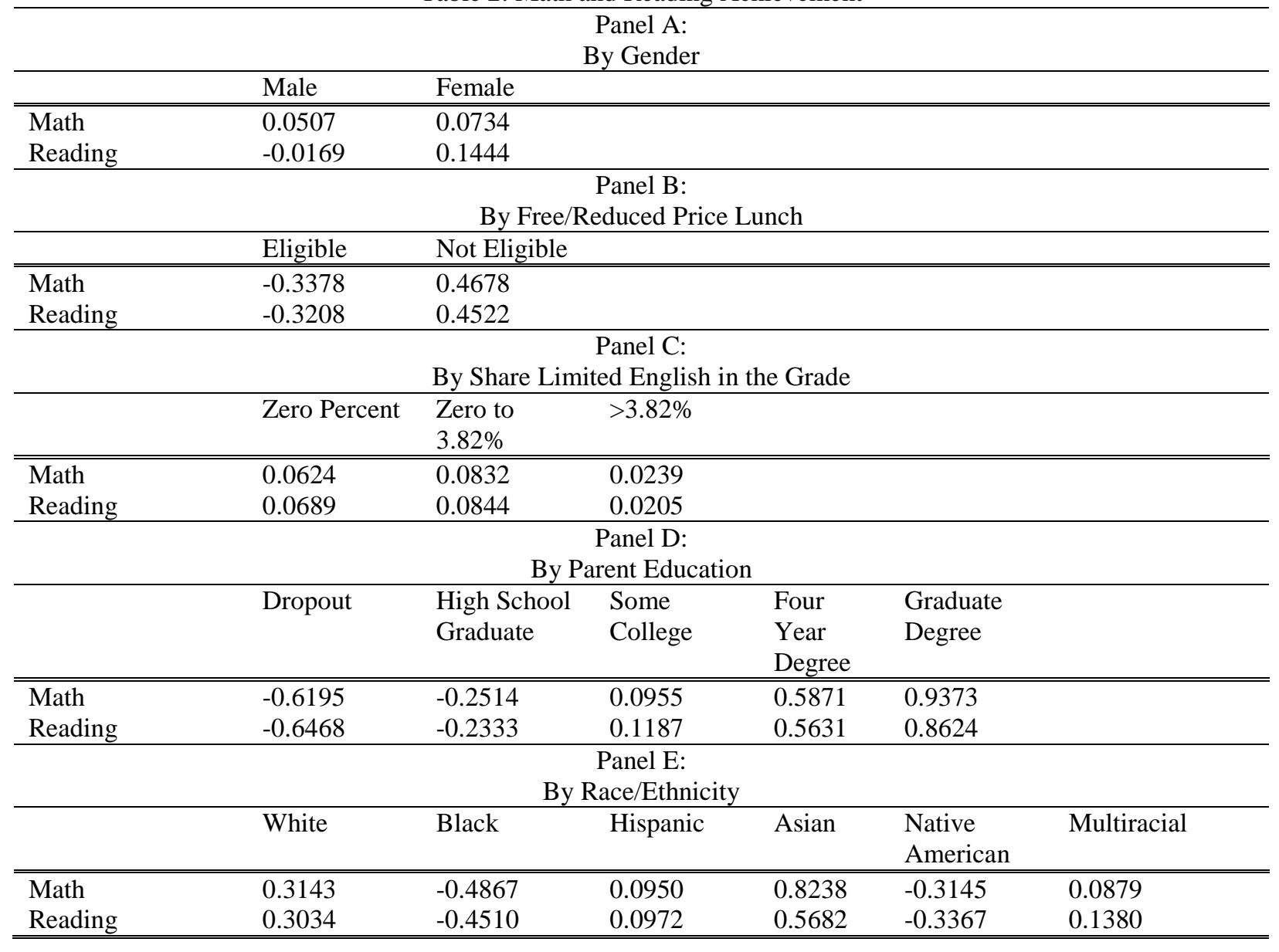


Table 3: Preliminary Regressions for Math

\begin{tabular}{|c|c|c|c|c|c|}
\hline VARIABLES & $\begin{array}{c}\text { Base } \\
(1) \\
\end{array}$ & $\begin{array}{c}\text { Plus Peers } \\
(2) \\
\end{array}$ & $\begin{array}{c}\text { Plus School } \\
\text { (3) } \\
\end{array}$ & $\begin{array}{c}\text { Plus Teacher } \\
\text { (4) }\end{array}$ & $\begin{array}{c}\text { Plus School Fixed } \\
\text { Effect } \\
(5) \\
\end{array}$ \\
\hline Share of Limited English & $\begin{array}{c}-0.0139 * \\
(0.008)\end{array}$ & $\begin{array}{c}-0.0227 * * * \\
(0.009)\end{array}$ & $\begin{array}{c}-0.0155^{*} \\
(0.009)\end{array}$ & $\begin{array}{c}-0.0267^{* * *} \\
(0.009)\end{array}$ & $\begin{array}{c}-0.0235^{* *} \\
(0.010)\end{array}$ \\
\hline Previous Year Math Z-Score & $\begin{array}{c}0.801^{* * *} \\
(0.000)\end{array}$ & $\begin{array}{c}0.800 * * * \\
(0.000)\end{array}$ & $\begin{array}{c}0.800^{* * *} \\
(0.000)\end{array}$ & $\begin{array}{c}0.799 * * * \\
(0.000)\end{array}$ & $\begin{array}{c}0.799 * * * \\
(0.000)\end{array}$ \\
\hline Latino & $\begin{array}{c}0.0546 * * * \\
(0.002)\end{array}$ & $\begin{array}{c}0.0623 * * * \\
(0.002)\end{array}$ & $\begin{array}{c}0.0625 * * * \\
(0.002)\end{array}$ & $\begin{array}{c}0.0621 * * * \\
(0.002)\end{array}$ & $\begin{array}{c}0.0608 * * * \\
(0.002)\end{array}$ \\
\hline Black & $\begin{array}{c}-0.0892 * * * \\
(0.001)\end{array}$ & $\begin{array}{c}-0.0700 * * * \\
(0.001)\end{array}$ & $\begin{array}{c}-0.0701 * * * \\
(0.001)\end{array}$ & $\begin{array}{c}-0.0705^{* * *} \\
(0.001)\end{array}$ & $\begin{array}{c}-0.0713^{* * *} \\
(0.001)\end{array}$ \\
\hline Asian & $\begin{array}{c}0.137 * * * \\
(0.003)\end{array}$ & $\begin{array}{c}0.139 * * * \\
(0.003)\end{array}$ & $\begin{array}{c}0.139 * * * \\
(0.003)\end{array}$ & $\begin{array}{c}0.139 * * * \\
(0.003)\end{array}$ & $\begin{array}{c}0.139 * * * \\
(0.003)\end{array}$ \\
\hline Native American & $\begin{array}{c}-0.0635^{* * *} \\
(0.003)\end{array}$ & $\begin{array}{c}-0.0455^{* * *} \\
(0.003)\end{array}$ & $\begin{array}{c}-0.0455^{* * *} \\
(0.003)\end{array}$ & $\begin{array}{c}-0.0457^{* * *} \\
(0.003)\end{array}$ & $\begin{array}{c}-0.0459 * * * \\
(0.003)\end{array}$ \\
\hline Multi-racial & $\begin{array}{c}-0.0101^{* * *} \\
(0.003)\end{array}$ & $\begin{array}{c}-0.00363 \\
(0.003)\end{array}$ & $\begin{array}{c}-0.00367 \\
(0.003)\end{array}$ & $\begin{array}{c}-0.00392 \\
(0.003)\end{array}$ & $\begin{array}{c}-0.00470 * \\
(0.003)\end{array}$ \\
\hline Female & $\begin{array}{c}0.0204 * * * \\
(0.001)\end{array}$ & $\begin{array}{c}0.0202 * * * \\
(0.001)\end{array}$ & $\begin{array}{c}0.0203^{* * *} \\
(0.001)\end{array}$ & $\begin{array}{c}0.0200 * * * \\
(0.001)\end{array}$ & $\begin{array}{c}0.0199 * * * \\
(0.001)\end{array}$ \\
\hline Parent high sch. dropout & $\begin{array}{c}-0.0617 * * * \\
(0.001)\end{array}$ & $\begin{array}{c}-0.0653 * * * \\
(0.001)\end{array}$ & $\begin{array}{c}-0.0653^{* * *} \\
(0.001)\end{array}$ & $\begin{array}{c}-0.0671^{* * *} \\
(0.001)\end{array}$ & $\begin{array}{c}-0.0673^{* * *} \\
(0.001)\end{array}$ \\
\hline Parent some college & $\begin{array}{c}0.0539 * * * \\
(0.001)\end{array}$ & $\begin{array}{c}0.0537 * * * \\
(0.001)\end{array}$ & $\begin{array}{c}0.0537 * * * \\
(0.001)\end{array}$ & $\begin{array}{c}0.0530 * * * \\
(0.001)\end{array}$ & $\begin{array}{c}0.0528 * * * \\
(0.001)\end{array}$ \\
\hline Parent with bachelor & $\begin{array}{c}0.124 * * * \\
(0.001)\end{array}$ & $\begin{array}{c}0.124 * * * \\
(0.001)\end{array}$ & $\begin{array}{c}0.124 * * * \\
(0.001)\end{array}$ & $\begin{array}{c}0.123 * * * \\
(0.001)\end{array}$ & $\begin{array}{c}0.122 * * * \\
(0.001)\end{array}$ \\
\hline Parent with graduate ed & $\begin{array}{c}0.189 * * * \\
(0.001)\end{array}$ & $\begin{array}{c}0.187 * * * \\
(0.001)\end{array}$ & $\begin{array}{c}0.187 * * * \\
(0.001)\end{array}$ & $\begin{array}{c}0.186 * * * \\
(0.001)\end{array}$ & $\begin{array}{c}0.184 * * * \\
(0.001)\end{array}$ \\
\hline Free lunch ever & $\begin{array}{c}-0.0902 * * * \\
(0.001)\end{array}$ & $\begin{array}{c}-0.0846^{* * *} \\
(0.001)\end{array}$ & $\begin{array}{c}-0.0845^{* * *} \\
(0.001)\end{array}$ & $\begin{array}{c}-0.0842 * * * \\
(0.001)\end{array}$ & $\begin{array}{c}-0.0839 * * * \\
(0.001)\end{array}$ \\
\hline Reduced lunch ever & $\begin{array}{c}-0.0472 * * * \\
(0.001)\end{array}$ & $\begin{array}{c}-0.0434 * * * \\
(0.001)\end{array}$ & $\begin{array}{c}-0.0434 * * * \\
(0.001)\end{array}$ & $\begin{array}{c}-0.0432 * * * \\
(0.001)\end{array}$ & $\begin{array}{c}-0.0428 * * * \\
(0.001)\end{array}$ \\
\hline Share of student AmInd & & $\begin{array}{c}-0.0281^{* * *} \\
(0.006)\end{array}$ & $\begin{array}{c}-0.0250 * * * \\
(0.006)\end{array}$ & $\begin{array}{c}0.00393 \\
(0.013)\end{array}$ & $\begin{array}{c}0.0341^{* *} \\
(0.014)\end{array}$ \\
\hline Share of student Asian & & $\begin{array}{c}0.132 * * * \\
(0.012)\end{array}$ & $\begin{array}{c}0.133^{* * *} \\
(0.012)\end{array}$ & $\begin{array}{c}0.184^{* * * *} \\
(0.012)\end{array}$ & $\begin{array}{c}0.164 * * * \\
(0.015)\end{array}$ \\
\hline Share student Multiracial & & $\begin{array}{c}-0.0533 * * * \\
(0.019)\end{array}$ & $\begin{array}{c}-0.0503 * * * \\
(0.019)\end{array}$ & $\begin{array}{c}-0.0886 * * * \\
(0.020)\end{array}$ & $\begin{array}{c}-0.0655^{* * *} \\
(0.021)\end{array}$ \\
\hline Share of student Black & & $\begin{array}{c}-0.0688 * * * \\
(0.002)\end{array}$ & $\begin{array}{c}-0.0653 * * * \\
(0.002)\end{array}$ & $\begin{array}{c}0.00676 * * \\
(0.003)\end{array}$ & $\begin{array}{c}0.00872 * * \\
(0.004)\end{array}$ \\
\hline Share of grade free lunch & & $-0.0141 * * *$ & $-0.0170 * * *$ & 0.00549 & -0.00108 \\
\hline
\end{tabular}


Share of grade reduced lunch

Pupil teacher ratio

Magnet

Charter School

$\%$ school free/reduced lunch

School location city

School location town

School location rural

Mean no of female teachers

Mean no of Asian teachers

Mean no of Black teachers

Mean no of Latino teachers

Mean no of other teachers

Mean no teacher first year

Mean no teacher with

Average teacher test scores

\begin{tabular}{cccccc} 
& & & $(0.002)$ & $(0.002)$ \\
Constant & $-0.00729^{* * *}$ & $0.0127^{* * *}$ & $0.0149 * * *$ & $-0.232^{* * *}$ & $-0.252^{* * *}$ \\
& $(0.001)$ & $(0.001)$ & $(0.002)$ & $(0.005)$ & $(0.007)$ \\
Grade Fixed Effects & Yes & Yes & Yes & Yes & Yes \\
Year Fixed Effects & Yes & Yes & Yes & Yes & Yes \\
\hline Observations & $3,094,280$ & $3,094,280$ & $3,094,280$ & $3,094,280$ & $3,094,280$ \\
R-squared & 0.742 & 0.743 & 0.743 & 0.743 & 0.747 \\
\hline \hline
\end{tabular}

\begin{tabular}{|c|c|c|c|}
\hline$(0.003)$ & $(0.004)$ & $(0.004)$ & $(0.004)$ \\
\hline$-0.0523 * * *$ & $-0.0561 * * *$ & $-0.0379 * * *$ & $-0.0379 * * *$ \\
\hline \multirow[t]{31}{*}{$(0.006)$} & $(0.007)$ & $(0.007)$ & $(0.007)$ \\
\hline & $-0.000364 * * *$ & $-0.000300 * * *$ & 4.79E-05 \\
\hline & $(0.000)$ & $(0.000)$ & $(0.000)$ \\
\hline & $-0.00362 * * *$ & -0.000972 & $0.00360 * *$ \\
\hline & $(0.001)$ & $(0.001)$ & $(0.001)$ \\
\hline & $-0.0606 * * *$ & $-0.0222 * * *$ & $-0.0110 *$ \\
\hline & $(0.006)$ & $(0.006)$ & $(0.006)$ \\
\hline & -0.0052 & $-0.00623^{*}$ & -0.00378 \\
\hline & $(0.003)$ & (0.003) & $(0.004)$ \\
\hline & $0.00717^{* * *}$ & $0.00362 * * *$ & $0.00782 * * *$ \\
\hline & $(0.001)$ & $(0.001)$ & $(0.001)$ \\
\hline & $0.00604^{* * *}$ & $0.00218 * *$ & $0.00689 * * *$ \\
\hline & $(0.001)$ & $(0.001)$ & $(0.001)$ \\
\hline & $0.00823^{* * *}$ & $0.00863 * * *$ & $0.00707 * * *$ \\
\hline & $(0.001)$ & $(0.001)$ & $(0.001)$ \\
\hline & & $0.249 * * *$ & $0.255^{* * *}$ \\
\hline & & $(0.005)$ & $(0.006)$ \\
\hline & & $-0.227 * * *$ & $-0.271 * * *$ \\
\hline & & $(0.046)$ & (0.059) \\
\hline & & $-0.101 * * *$ & $-0.0941 * * *$ \\
\hline & & $(0.004)$ & $(0.005)$ \\
\hline & & $0.325 * * *$ & $0.260 * * *$ \\
\hline & & $(0.024)$ & $(0.029)$ \\
\hline & & -0.0249 & $-0.0453 * *$ \\
\hline & & $(0.017)$ & (0.019) \\
\hline & & $-0.155^{* * *}$ & $-0.214 * * *$ \\
\hline & & (0.009) & $(0.011)$ \\
\hline & & $0.0341 * * *$ & $0.0741^{* * *}$ \\
\hline & & $(0.004)$ & $(0.005)$ \\
\hline & & 0.00105 & $-0.0151 * * *$ \\
\hline & & $(0.002)$ & $(0.002)$ \\
\hline $0.0127 * * *$ & $0.0149 * * *$ & $-0.232 * * *$ & $-0.252 * * *$ \\
\hline$(0.001)$ & $(0.002)$ & $(0.005)$ & $(0.007)$ \\
\hline Yes & Yes & Yes & Yes \\
\hline Yes & Yes & Yes & Yes \\
\hline $3,094,280$ & $3,094,280$ & $3,094,280$ & $3,094,280$ \\
\hline 0.743 & 0.743 & 0.743 & 0.747 \\
\hline
\end{tabular}


Table 4: Preliminary Regressions for Reading

\begin{tabular}{|c|c|c|c|c|c|}
\hline VARIABLES & $\begin{array}{c}\text { Base } \\
(1) \\
\end{array}$ & $\begin{array}{c}\text { Plus Peers } \\
(2) \\
\end{array}$ & $\begin{array}{c}\text { Plus School } \\
\text { (3) } \\
\end{array}$ & $\begin{array}{c}\text { Plus Teacher } \\
\text { (4) } \\
\end{array}$ & $\begin{array}{c}\text { Plus School Fixed } \\
\text { Effect } \\
(5) \\
\end{array}$ \\
\hline \multirow[t]{2}{*}{ Share of Limited English } & $-0.0432 * * *$ & $-0.0256 * * *$ & $-0.0196 * *$ & $-0.0250 * *$ & $-0.0347 * * *$ \\
\hline & $(0.008)$ & $(0.009)$ & $(0.010)$ & $(0.010)$ & $(0.011)$ \\
\hline \multirow[t]{2}{*}{ Previous Year Reading Z-Score } & $0.753^{* * *}$ & $0.752 * * *$ & $0.752 * * *$ & $0.752 * * *$ & $0.751 * * *$ \\
\hline & $(0.000)$ & $(0.000)$ & $(0.000)$ & $(0.000)$ & $(0.000)$ \\
\hline \multirow[t]{2}{*}{ Latino } & $0.0552 * * *$ & $0.0577 * * *$ & $0.0578 * * *$ & $0.0572 * * *$ & $0.0568 * * *$ \\
\hline & $(0.002)$ & $(0.002)$ & $(0.002)$ & $(0.002)$ & $(0.002)$ \\
\hline \multirow[t]{2}{*}{ Black } & $-0.114 * * *$ & $-0.103^{* * *}$ & $-0.103 * * *$ & $-0.104 * * *$ & $-0.104 * * *$ \\
\hline & $(0.001)$ & $(0.001)$ & $(0.001)$ & $(0.001)$ & $(0.001)$ \\
\hline \multirow[t]{2}{*}{ Asian } & $0.0774 * * *$ & $0.0745 * * *$ & $0.0742 * * *$ & $0.0745 * * *$ & $0.0743 * * *$ \\
\hline & $(0.003)$ & $(0.003)$ & $(0.003)$ & $(0.003)$ & $(0.003)$ \\
\hline \multirow[t]{2}{*}{ Native American } & $-0.0828 * * *$ & $-0.0546 * * *$ & $-0.0547 * * *$ & $-0.0550 * * *$ & $-0.0557 * * *$ \\
\hline & $(0.003)$ & $(0.004)$ & $(0.004)$ & $(0.004)$ & $(0.004)$ \\
\hline \multirow[t]{2}{*}{ Multiracial } & 0.000 & 0.000 & -0.001 & -0.001 & -0.001 \\
\hline & $(0.003)$ & $(0.003)$ & $(0.003)$ & $(0.003)$ & $(0.003)$ \\
\hline Female & $0.0485 * * *$ & $0.0484 * * *$ & $0.0484 * * *$ & $0.0483 * * *$ & $0.0483 * * *$ \\
\hline & $(0.001)$ & $(0.001)$ & $(0.001)$ & $(0.001)$ & $(0.001)$ \\
\hline Free lunch ever & $\begin{array}{c}-0.101^{* * *} \\
(0.001)\end{array}$ & $\begin{array}{c}-0.0950 * * * \\
(0.001)\end{array}$ & $\begin{array}{c}-0.0950 * * * \\
(0.001)\end{array}$ & $\begin{array}{c}-0.0949 * * * \\
(0.001)\end{array}$ & $\begin{array}{c}-0.0952 * * * \\
(0.001)\end{array}$ \\
\hline Reduced lunch ever & $\begin{array}{c}-0.0464 * * * \\
(0.001)\end{array}$ & $\begin{array}{c}-0.0442 * * * \\
(0.001)\end{array}$ & $\begin{array}{c}-0.0441 * * * \\
(0.001)\end{array}$ & $\begin{array}{c}-0.0441 * * * \\
(0.001)\end{array}$ & $\begin{array}{c}-0.0443 * * * \\
(0.001)\end{array}$ \\
\hline Pupil teacher ratios & & & $\begin{array}{c}-0.000626^{* * *} \\
(0.000)\end{array}$ & $\begin{array}{c}-0.000516^{* * *} \\
(0.000)\end{array}$ & $\begin{array}{c}-0.000246 * * \\
(0.000)\end{array}$ \\
\hline Average no female teachers & & & & $\begin{array}{c}0.178 * * * \\
(0.005)\end{array}$ & $\begin{array}{c}0.195^{* * *} \\
(0.007)\end{array}$ \\
\hline Average no first year teachers & & & & $\begin{array}{c}-0.194^{* * * *} \\
(0.010)\end{array}$ & $\begin{array}{c}-0.196^{* * * *} \\
(0.012)\end{array}$ \\
\hline Average no teacher with masters & & & & $\begin{array}{c}0.00870^{* *} \\
(0.004)\end{array}$ & $\begin{array}{c}0.0132 * * \\
(0.006)\end{array}$ \\
\hline Teacher test mean & & & & $\begin{array}{c}0.0117 * * * \\
(0.002)\end{array}$ & $\begin{array}{c}0.004 \\
(0.003)\end{array}$ \\
\hline Constant & Yes & Yes & Yes & Yes & Yes \\
\hline Year Fixed Effects & Yes & Yes & Yes & Yes & Yes \\
\hline Grade Fixed Effects & Yes & Yes & Yes & Yes & Yes \\
\hline Parent Education dummies & Yes & Yes & Yes & Yes & Yes \\
\hline Share of free lunch students & No & Yes & Yes & Yes & Yes \\
\hline Share of pupils on reduced lunch & No & Yes & Yes & Yes & Yes \\
\hline Share of students by race dummies & No & Yes & Yes & Yes & Yes \\
\hline magnet school dummy & No & No & Yes & Yes & Yes \\
\hline Charter School Dummy & No & No & Yes & Yes & Yes \\
\hline School location Dummies & No & No & Yes & Yes & Yes \\
\hline$\%$ of school free/reduced lunch & No & No & Yes & Yes & Yes \\
\hline Average Teacher race dummies & No & No & No & Yes & Yes \\
\hline Observations & $3,077,518$ & $3,077,518$ & $3,077,518$ & $3,077,518$ & $3,077,518$ \\
\hline R-squared & 0.686 & 0.686 & 0.686 & 0.686 & 0.688 \\
\hline
\end{tabular}


Table 5: Effect of Increases in Immigrant shares on achievement

\begin{tabular}{cccc}
\hline & $\begin{array}{c}\text { School by Year } \\
(1)\end{array}$ & $\begin{array}{c}\text { School by Grade } \\
(2)\end{array}$ & $\begin{array}{c}\text { Individual Fixed Effects } \\
(3)\end{array}$ \\
\hline \hline & & Panel A (Math) & \\
Share of Limited & & $0.0572^{* * *}$ & $-0.0337^{* * *}$ \\
English & $-0.0516^{* *}$ & $(0.014)$ & $(0.012)$ \\
& $(0.024)$ & 3094280. & 3094280. \\
Observations & 3094280. & 0.754 & 0.009 \\
R-squared & 0.754 & Panel B & \\
& & $($ English) & $0.0244^{*}$ \\
Share of Limited & & 0.000 & $(0.014)$ \\
English & $-0.0579 * *$ & $(0.016)$ & 3077518 \\
& $(0.026)$ & 3077518 & 0.019 \\
\hline Observations & 3077518 & 0.691 & \\
\hline R-squared & 0.692 & &
\end{tabular}

Note: This table summarizes the estimates of the impact of immigrant shares on test scores from six separate regressions. The controls highlighted in Table 3 are also included in each regression.

Table 6: Effect of Increases in Immigrant Shares on Achievement by Achievement Rank

\begin{tabular}{|c|c|c|c|c|}
\hline \multirow[b]{2}{*}{ Percentile } & \multicolumn{2}{|c|}{ Panel A } & \multicolumn{2}{|c|}{ Panel B } \\
\hline & $\begin{array}{c}\text { Math } \\
\text { School by- } \\
\text { Year } \\
(1)\end{array}$ & $\begin{array}{c}\text { Math } \\
\text { School by } \\
\text { Grade } \\
(2)\end{array}$ & $\begin{array}{c}\text { Reading } \\
\text { School by- } \\
\text { Year } \\
(3) \\
\end{array}$ & $\begin{array}{c}\text { Reading } \\
\text { School by } \\
\text { Grade } \\
(4)\end{array}$ \\
\hline Top 25\% & $\begin{array}{c}-0.0823^{* *} \\
(0.04)\end{array}$ & $\begin{array}{c}-0.0046 \\
(0.02)\end{array}$ & $\begin{array}{c}-0.0780 * * \\
(0.03)\end{array}$ & $\begin{array}{c}-0.0421^{* *} \\
(0.02)\end{array}$ \\
\hline $\begin{array}{c}\text { Bottom } \\
25 \%\end{array}$ & $\begin{array}{l}0.013 \\
(0.03)\end{array}$ & $\begin{array}{c}0.0821 * * * \\
\quad(0.02)\end{array}$ & $\begin{array}{c}-0.0378 \\
(0.05)\end{array}$ & $\begin{array}{c}0.0121 \\
(0.03)\end{array}$ \\
\hline $\begin{array}{l}\text { Middle } \\
50 \%\end{array}$ & $\begin{array}{c}0.0168 \\
(0.02)\end{array}$ & $\begin{array}{c}0.0464^{* * *} \\
(0.01)\end{array}$ & $\begin{array}{l}-0.03 \\
(0.02)\end{array}$ & $\begin{array}{c}-0.0204 \\
(0.01)\end{array}$ \\
\hline
\end{tabular}

Note: This table summarizes the estimates of the impact of immigrant shares on test scores from twelve separate regressions. The controls highlighted in Table 3 are also included in each regression. 
Table 7: Immigrant Peer Effects by Immigrant Thresholds

\begin{tabular}{|c|c|c|c|c|c|c|}
\hline \multirow[b]{3}{*}{ Threshold } & \multicolumn{3}{|c|}{ Panel A (Math) } & \multicolumn{3}{|c|}{ Panel B (Reading) } \\
\hline & $\begin{array}{c}\text { School by } \\
\text { Year }\end{array}$ & $\begin{array}{l}\text { School by } \\
\text { Grade }\end{array}$ & Individual & $\begin{array}{c}\text { School by } \\
\text { Year }\end{array}$ & $\begin{array}{c}\text { School by } \\
\text { Grade }\end{array}$ & Individual \\
\hline & $\begin{array}{l}\text { Fixed Effects } \\
\text { (1) }\end{array}$ & $\begin{array}{c}\text { Fixed Effects } \\
\text { (2) }\end{array}$ & $\begin{array}{l}\text { Fixed Effects } \\
\text { (3) }\end{array}$ & $\begin{array}{c}\text { Fixed Effects } \\
\text { (1) }\end{array}$ & $\begin{array}{c}\text { Fixed Effects } \\
\text { (2) }\end{array}$ & $\begin{array}{c}\text { Fixed Effects } \\
\text { (3) }\end{array}$ \\
\hline & & Panel A & & & Panel B & \\
\hline Above Zero & $\begin{array}{c}-0.0518^{* *} \\
(0.024)\end{array}$ & $\begin{array}{c}0.0571^{* * *} \\
(0.014)\end{array}$ & $\begin{array}{c}-0.0339 * * * \\
(0.012)\end{array}$ & $\begin{array}{c}-0.0579 * * \\
(0.026)\end{array}$ & $\begin{array}{c}0.00037 \\
(0.016)\end{array}$ & $\begin{array}{c}0.0244^{*} \\
(0.014)\end{array}$ \\
\hline Above $1 \%$ & $\begin{array}{c}-0.0526^{* *} \\
(0.024)\end{array}$ & $\begin{array}{c}0.0610^{* * *} \\
(0.014)\end{array}$ & $\begin{array}{c}-0.0345^{* * *} \\
(0.012)\end{array}$ & $\begin{array}{c}-0.0572 * * \\
(0.026)\end{array}$ & $\begin{array}{c}0.00422 \\
(0.016)\end{array}$ & $\begin{array}{c}0.0234^{*} \\
(0.014)\end{array}$ \\
\hline Above $4 \%$ & $\begin{array}{c}-0.0549 * * \\
(0.024)\end{array}$ & $\begin{array}{c}0.0640 * * * \\
(0.014)\end{array}$ & $\begin{array}{c}-0.0330 * * * \\
(0.012)\end{array}$ & $\begin{array}{c}-0.0583 * * \\
(0.026)\end{array}$ & $\begin{array}{c}0.00624 \\
(0.016)\end{array}$ & $\begin{array}{c}0.0258 * \\
(0.014)\end{array}$ \\
\hline Above 5\% & $\begin{array}{c}-0.0528 * * \\
(0.024)\end{array}$ & $\begin{array}{c}0.0637^{* * *} \\
(0.014)\end{array}$ & $\begin{array}{c}-0.0325^{* * *} \\
(0.013)\end{array}$ & $\begin{array}{c}-0.0598 * * \\
(0.026)\end{array}$ & $\begin{array}{c}0.00444 \\
(0.016)\end{array}$ & $\begin{array}{l}0.0207 \\
(0.014)\end{array}$ \\
\hline Above $10 \%$ & $\begin{array}{c}-0.0522^{* *} \\
(0.024)\end{array}$ & $\begin{array}{c}0.0753^{* * *} \\
(0.015)\end{array}$ & $\begin{array}{c}-0.0218^{*} \\
(0.013)\end{array}$ & $\begin{array}{c}-0.0633^{* *} \\
(0.027)\end{array}$ & $\begin{array}{l}0.0179 \\
(0.016)\end{array}$ & $\begin{array}{c}0.019 \\
(0.015)\end{array}$ \\
\hline Above $20 \%$ & $\begin{array}{c}-0.0834 * * * \\
(0.027) \\
\end{array}$ & $\begin{array}{c}0.0414^{* *} \\
(0.017) \\
\end{array}$ & $\begin{array}{c}-0.0735^{* * *} \\
(0.017) \\
\end{array}$ & $\begin{array}{c}-0.0859 * * * \\
(0.030) \\
\end{array}$ & $\begin{array}{l}0.0248 \\
(0.019) \\
\end{array}$ & $\begin{array}{c}-0.0320 * \\
(0.018)\end{array}$ \\
\hline
\end{tabular}

Note: This table summarizes the estimates of the impact of immigrant shares on test scores from 36 separate regressions. The controls highlighted in Table 3 are also included in each regression. 
Table 8 Robustness Checks on Heterogeneous Impacts

\begin{tabular}{|c|c|c|c|c|}
\hline Threshold & $\begin{array}{c}\text { math } \\
\text { School by-Year } \\
\text { (1) }\end{array}$ & $\begin{array}{c}\text { math } \\
\text { School by Grade } \\
\text { (2) }\end{array}$ & $\begin{array}{c}\text { reading } \\
\text { School by-Year } \\
\text { (3) }\end{array}$ & $\begin{array}{c}\text { reading } \\
\text { School by Grade } \\
\text { (4) }\end{array}$ \\
\hline \multicolumn{5}{|c|}{ Panel A ( Top 25\% of Native Students) } \\
\hline $\begin{array}{l}\text { Above } \\
\text { ZERO }\end{array}$ & $\begin{array}{c}-0.0827 * * \\
(0.037)\end{array}$ & $\begin{array}{c}-0.00479 \\
(0.023)\end{array}$ & $\begin{array}{c}-0.0779 * * \\
(0.034)\end{array}$ & $\begin{array}{c}-0.0421 * * \\
(0.021)\end{array}$ \\
\hline Above $1 \%$ & $\begin{array}{c}-0.0827 * * \\
(0.037)\end{array}$ & $\begin{array}{c}-0.00434 \\
(0.023)\end{array}$ & $\begin{array}{c}-0.0779 * * \\
(0.034)\end{array}$ & $\begin{array}{c}-0.0415 * * \\
(0.021)\end{array}$ \\
\hline Above $4 \%$ & $\begin{array}{c}-0.0874 * * \\
(0.037)\end{array}$ & $\begin{array}{c}-0.00402 \\
(0.023)\end{array}$ & $\begin{array}{c}-0.0771^{* *} \\
(0.034)\end{array}$ & $\begin{array}{c}-0.0419 * * \\
(0.021)\end{array}$ \\
\hline Above 5\% & $\begin{array}{c}-0.0846^{* *} \\
(0.037)\end{array}$ & $\begin{array}{c}-0.00224 \\
(0.023)\end{array}$ & $\begin{array}{c}-0.0799 * * \\
(0.034)\end{array}$ & $\begin{array}{c}-0.0425 * * \\
(0.021)\end{array}$ \\
\hline Above $10 \%$ & $\begin{array}{c}-0.0845^{* *} \\
(0.039)\end{array}$ & $\begin{array}{c}0.000322 \\
(0.023)\end{array}$ & $\begin{array}{c}-0.0984 * * * \\
(0.035)\end{array}$ & $\begin{array}{r}-0.0311 \\
(0.022)\end{array}$ \\
\hline Above $20 \%$ & $\begin{array}{c}-0.0810^{*} \\
(0.044)\end{array}$ & $\begin{array}{r}-0.0332 \\
(0.027)\end{array}$ & $\begin{array}{c}-0.0890^{* *} \\
(0.040)\end{array}$ & $\begin{array}{r}-0.0277 \\
(0.025)\end{array}$ \\
\hline \multicolumn{5}{|c|}{ Panel B ( Bottom 25\% of Native Students) } \\
\hline $\begin{array}{l}\text { Above } \\
\text { ZERO }\end{array}$ & $\begin{array}{c}0.013 \\
(0.035)\end{array}$ & $\begin{array}{c}0.0821^{* * *} \\
(0.021)\end{array}$ & $\begin{array}{c}-0.0379 \\
(0.046)\end{array}$ & $\begin{array}{c}0.012 \\
(0.027)\end{array}$ \\
\hline Above $1 \%$ & $\begin{array}{l}0.0142 \\
(0.035)\end{array}$ & $\begin{array}{c}0.0853^{* * *} \\
(0.021)\end{array}$ & $\begin{array}{r}-0.0368 \\
(0.046)\end{array}$ & $\begin{array}{l}0.0171 \\
(0.027)\end{array}$ \\
\hline Above $4 \%$ & $\begin{array}{l}0.0125 \\
(0.035)\end{array}$ & $\begin{array}{c}0.0862 * * * \\
(0.021)\end{array}$ & $\begin{array}{r}-0.0357 \\
(0.046)\end{array}$ & $\begin{array}{l}0.0181 \\
(0.027)\end{array}$ \\
\hline Above $5 \%$ & $\begin{array}{c}0.00973 \\
(0.035)\end{array}$ & $\begin{array}{c}0.0859 * * * \\
(0.021)\end{array}$ & $\begin{array}{r}-0.0375 \\
(0.046)\end{array}$ & $\begin{array}{c}0.017 \\
(0.027)\end{array}$ \\
\hline Above $10 \%$ & $\begin{array}{c}-0.00111 \\
(0.035)\end{array}$ & $\begin{array}{c}0.0851 * * * \\
(0.021)\end{array}$ & $\begin{array}{l}-0.0451 \\
(0.047)\end{array}$ & $\begin{array}{c}0.0251 \\
(0.028)\end{array}$ \\
\hline Above $20 \%$ & $\begin{array}{c}-0.00429 \\
(0.039)\end{array}$ & $\begin{array}{c}0.0750^{* * *} \\
(0.025)\end{array}$ & $\begin{array}{c}-0.0929 * \\
(0.052)\end{array}$ & $\begin{array}{c}0.00505 \\
(0.033)\end{array}$ \\
\hline
\end{tabular}

Note: This table summarizes the estimates of the impact of immigrant shares on test scores from 48 separate regressions. The controls highlighted in Table 3 are also included in each regression. 
Table 8 (Continued): Robustness Checks on Heterogeneous Impacts

\begin{tabular}{|c|c|c|c|c|}
\hline Threshold & $\begin{array}{c}\text { math } \\
\text { School by- } \\
\text { Year } \\
(1)\end{array}$ & $\begin{array}{c}\text { math } \\
\text { School by } \\
\text { Grade } \\
(2)\end{array}$ & $\begin{array}{c}\text { reading } \\
\text { School by- } \\
\text { Year } \\
(3) \\
\end{array}$ & $\begin{array}{c}\text { reading } \\
\text { School by } \\
\text { Grade } \\
(4)\end{array}$ \\
\hline \multicolumn{5}{|c|}{ [Panel C: Middle 50\%] } \\
\hline $\begin{array}{l}\text { Above } \\
\text { ZERO }\end{array}$ & $\begin{array}{l}0.0167 \\
(0.021)\end{array}$ & $\begin{array}{c}0.0464 * * * \\
(0.013)\end{array}$ & $\begin{array}{l}-0.0299 \\
(0.021)\end{array}$ & $\begin{array}{l}-0.0203 \\
(0.013)\end{array}$ \\
\hline Above $1 \%$ & $\begin{array}{l}0.0167 \\
(0.021)\end{array}$ & $\begin{array}{c}0.0477 * * * \\
(0.013)\end{array}$ & $\begin{array}{c}-0.03 \\
(0.021)\end{array}$ & $\begin{array}{l}-0.0184 \\
(0.013)\end{array}$ \\
\hline Above $4 \%$ & $\begin{array}{l}0.0165 \\
(0.021)\end{array}$ & $\begin{array}{c}0.0514^{* * *} \\
(0.013)\end{array}$ & $\begin{array}{l}-0.0276 \\
(0.021)\end{array}$ & $\begin{array}{c}-0.0156 \\
(0.013)\end{array}$ \\
\hline Above $5 \%$ & $\begin{array}{l}0.0179 \\
(0.021)\end{array}$ & $\begin{array}{c}0.0517 * * * \\
(0.013)\end{array}$ & $\begin{array}{l}-0.0285 \\
(0.021)\end{array}$ & $\begin{array}{l}-0.0172 \\
(0.013)\end{array}$ \\
\hline $\begin{array}{c}\text { Above } \\
10 \%\end{array}$ & $\begin{array}{l}0.0222 \\
(0.021)\end{array}$ & $\begin{array}{c}0.0578 * * * \\
(0.013)\end{array}$ & $\begin{array}{l}-0.0307 \\
(0.022)\end{array}$ & $\begin{array}{c}-0.0154 \\
(0.013)\end{array}$ \\
\hline $\begin{array}{c}\text { Above } \\
20 \%\end{array}$ & $\begin{array}{c}-0.00993 \\
(0.024)\end{array}$ & $\begin{array}{c}0.0506 * * * \\
(0.015)\end{array}$ & $\begin{array}{c}-0.0515^{* *} \\
(0.024)\end{array}$ & $\begin{array}{l}-0.0181 \\
(0.015)\end{array}$ \\
\hline
\end{tabular}

Note: This table summarizes the estimates of the impact of immigrant shares on test scores from twenty four separate regressions. The controls highlighted in Table 3 are also included in each regression. 


\begin{tabular}{|c|c|c|c|c|c|}
\hline \multicolumn{6}{|c|}{$\begin{array}{c}\text { Appendix Table } 1 \\
\text { Descriptive Statistics }\end{array}$} \\
\hline & Full Sample & $\begin{array}{c}\text { High } \\
\text { Achievers } \\
\text { (Top 25\% } \\
\text { of Math Z- } \\
\text { Scores) } \\
\end{array}$ & $\begin{array}{c}\text { Middle } \\
\text { Achievers } \\
\text { (Middle } \\
50 \% \text { of } \\
\text { Math Z- } \\
\text { Scores) }\end{array}$ & $\begin{array}{c}\text { Low } \\
\text { Achievers } \\
\text { (Bottom } \\
25 \% \text { of } \\
\text { Math Z- } \\
\text { Scores) } \\
\end{array}$ & $\begin{array}{c}\text { Grade in } \\
\text { School with } \\
>\mathbf{2 0 \%} \\
\text { Limited } \\
\text { English in } \\
\text { at least One } \\
\text { Year } \\
\end{array}$ \\
\hline Number of Observations & $3,077,518$ & 834,028 & $1,520,767$ & 722,723 & $1,950,260$ \\
\hline $\begin{array}{l}\text { Fraction of Grade Currently } \\
\text { Limited English }\end{array}$ & 0.03 & 0.03 & 0.03 & 0.03 & 0.03 \\
\hline Test Z-Scores & & & & & \\
\hline Current Grade Math & 0.07 & 1.29 & 0.01 & -1.21 & 0.05 \\
\hline Previous Grade Math & 0.08 & 1.14 & 0.00 & -1.00 & 0.06 \\
\hline Current Grade Reading & 0.07 & 0.97 & 0.05 & -0.95 & 0.05 \\
\hline Previous Grade Reading & 0.08 & 0.95 & 0.05 & -0.87 & 0.06 \\
\hline Individual Demographics & & & & & \\
\hline White & 0.64 & 0.84 & 0.64 & 0.41 & 0.66 \\
\hline Hispanic & 0.02 & 0.02 & 0.02 & 0.01 & 0.02 \\
\hline Black & 0.30 & 0.10 & 0.30 & 0.54 & 0.29 \\
\hline Asian & 0.01 & 0.03 & 0.01 & 0.00 & 0.01 \\
\hline American Indian & 0.01 & 0.01 & 0.01 & 0.02 & 0.01 \\
\hline Multiracial & 0.01 & 0.01 & 0.01 & 0.01 & 0.01 \\
\hline Female & 0.50 & 0.49 & 0.52 & 0.48 & 0.50 \\
\hline $\begin{array}{l}\text { Individual Family } \\
\text { Characteristics }\end{array}$ & & & & & \\
\hline $\begin{array}{l}\text { Parent Education-Dropout } \\
\text { Parent Education-High School }\end{array}$ & 0.07 & 0.02 & 0.07 & 0.15 & 0.08 \\
\hline Graduate & 0.41 & 0.23 & 0.44 & 0.57 & 0.44 \\
\hline Parent Education-Some College & 0.22 & 0.21 & 0.24 & 0.18 & 0.23 \\
\hline $\begin{array}{l}\text { Parent Education-4 Year Degree } \\
\text { Parent Education-Graduate }\end{array}$ & 0.24 & 0.42 & 0.21 & 0.09 & 0.21 \\
\hline Degree & 0.06 & 0.13 & 0.04 & 0.01 & 0.05 \\
\hline $\begin{array}{l}\text { Ever Free Lunch Eligible } \\
\text { Ever Reduced Price Lunch }\end{array}$ & 0.44 & 0.18 & 0.45 & 0.71 & 0.45 \\
\hline Eligible & 0.07 & 0.05 & 0.07 & 0.06 & 0.07 \\
\hline
\end{tabular}




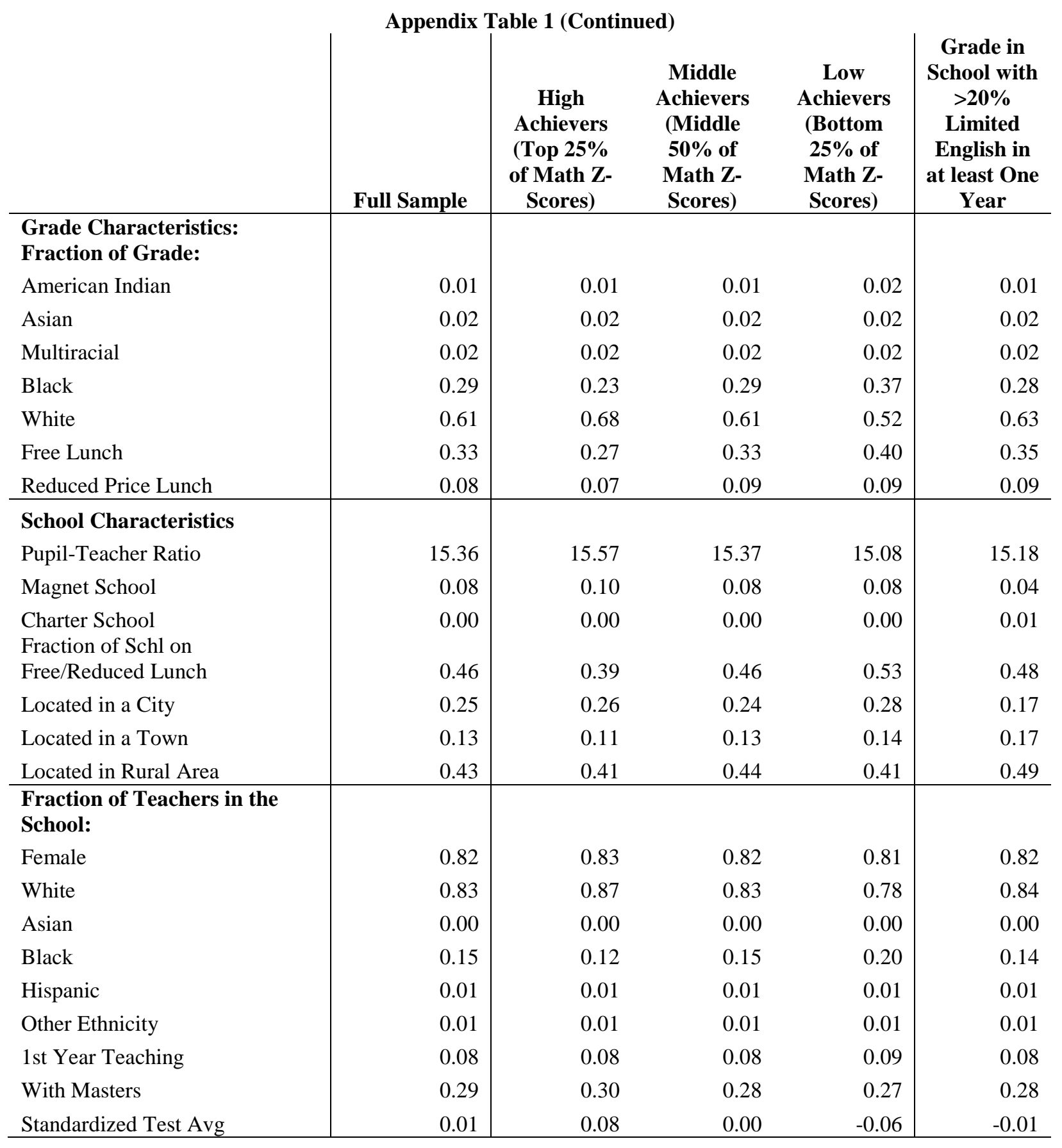

